\title{
Metacognitive Knowledge and Metacognitive Regulation in Self-Regulatory Learning Style, and in Its Effects on Performance Expectation and Subsequent Performance across Diverse School Subjects
}

\author{
Georgia Stephanou1, Maria-Helena Mpiontini2 \\ ${ }^{1}$ Faculty of Education, University of Western Macedonia, Florina, Greece \\ ${ }^{2}$ Hellenic Open University, Patra, Greece \\ Email: gstephanou@uowm.gr
}

How to cite this paper: Stephanou, G., \& Mpiontini, M. (2017). Metacognitive Knowledge and Metacognitive Regulation in Self-Regulatory Learning Style, and in Its Effects on Performance Expectation and Subsequent Performance across Diverse School Subjects. Psychology, 8, 1941-1975. https://doi.org/10.4236/psych.2017.812125

Received: September 4, 2017

Accepted: October 16, 2017

Published: October 19, 2017

Copyright $\odot 2017$ by authors and Scientific Research Publishing Inc. This work is licensed under the Creative Commons Attribution International License (CC BY 4.0).

http://creativecommons.org/licenses/by/4.0/

\begin{abstract}
This study aimed at examining: (a) students' metacognitive knowledge and metacognitive regulation when they are doing school work or homework, and their self-regulated learning style regarding the four different types of behavioral regulation: external, introjected, identified and intrinsic; and (b) the role of metacognition in self-regulated learning style, and in the impact of self-regulated learning style on performance expectations, and subsequent performance in the school subjects of language, mathematics and physical education. The sample comprised of 243 primary school students, fifth and sixth grades, boys and girls, who randomly came from 20 state primary schools of various regions of Greece. The participants completed the scales at the middle of a school year, while their school performance was estimated by the teachers. The results showed that: (a) the students used metacognitive knowledge (predominately, declarative) and metacognitive regulation (mainly, planning) at a moderate extent, and they reported a mixed profile of self-regulatory learning style, favoring identified; (b) metacognitive regulation, compared with metacognitive knowledge, was a more powerful formulator of regulatory learning styles, mainly intrinsic and identified; (c) metacognition explained a small percentage of variance of both performance expectations, beyond self-regulatory style, and performance, beyond the interactive effect of performance expectations and regulatory learning style, in both language and mathematics, while it had no significant unique contribution in physical education; (d) external regulation had negative contribution in school performance across the three school subjects, while intrinsic regulation
\end{abstract}


had no unique effect. Theoretical and practical applications of the findings are discussed.

\section{Keywords}

Metacognition, Performance Expectations, School Performance, Self-Regulatory Learning Style

\section{Introduction}

Metacognition and self-regulation are considered key competencies for successful learning in a wide range of domains, including education (Efklides, 2014; Gomes, Golino, \& Menezes, 2014; Panadero, 2017; Veenman, 2016; Veenman, Wilhelm, \& Beishuizen, 2004). Furthermore, to better understand metacognition requires a deeper look at self-regulation, and the literature often discusses metacognition and self-regulation concurrently (e.g., Efklides, 2008; 2011; Hacker, Dunlosky, \& Graesser, 2009; Pintrich, 2004; Schraw et al., 2006; Winne \& Nesbit, 2010; Zimmerman \& Schunk, 2011). This study, therefore, engages metacognition and self-regulation. This research, accurately, lies within a motivational self-determination perspective, since, although the relationship of metacognition and self-regulated learning is treated differently, it typically grounded in a social cognitive perspective (see Efklides, 2014; Veenman, van Hout-Wolters, \& Afflerbach, 2006; for an overview).

Most researchers in the field of metacognition (e.g., Brown, 1987; Efklides, 2001; 2008; Flavell, 1987; Jacobs \& Paris, 1987; Perry, 2013; Schraw \& Moshman, 1995; Tanner, 2012) conceptualize metacognition as metacognitive knowledge and metacognitive regulation which are mainly operationalized into monitoring (metacognitive knowledge and metacognitive experience) and regulatory (goals and activation of strategies) functions. Some authors further distinguish the regulation component into an experience and a skill component (see Händel, Artelt, \& Weinert, 2013). However, knowledge is not entirely discriminated from regulation of metacognition rather interact with each other. For instance, Efklides' (2011) model supports a complex interplay between a person level in which metacognitive knowledge and skills are, a task level and an interaction level in which metacognitive experiences are located. This study explores metacognitive knowledge and metacognitive regulation in students' school work and home work. Metacognitive knowledge can be defined as what we know about our own cognitive processes, and its subcomponents are declarative, procedural and conditional knowledge. Metacognitive regulation refers to the actual activities in which we engage in order to facilitate learning and memory, and it is broken down into component activities of planning, monitoring and evaluating. Students who have well developed metacognitive knowledge and metacognitive regulatory skills and who use their metacognition they will excel academically (see Artelt, Naumann, \& Schneider, 2010; Carr, 2010; Kostaridou-Efklides, 2011; 
Pintrich, 2002; Thillmann, 2008; Winne \& Nesbit, 2010).

Previous research indicates that metacognition is one of the key components in self-regulated learning which is defined as "the ways in which individuals regulate their own cognitive processes within an educational setting" (Puustinen $\&$ Pulkkinen, 2001: 269). Learners who have high metacognitive ability, are highly likely to monitor, control, and regulate their own learning behavior, thus resulting in the achievement of their learning goals (Alexander, 2008; Bruning, Schraw, \& Norby, 2011; Carr, 2010; Kostaridou-Efklides, 2011; Zimmerman, 1989).

In recent years, self-regulated learning itself has been increasingly an interesting research topic due to its fundamental importance in the teaching-learning process (Benbenutty, Cleary, \& Kitsantas, 2014; Boekaerts \& Corno, 2005; Chatzistamatiou \& Dermitzaki, 2013; De la Fuente, Zapata, Martínez-Vicente1, Sander, \& Cardelle-Elawar, 2015; Zimmerman \& Labuhn, 2012; Zumbrunn, Tadlock, \& Roberts, 2011). For instance, the extent to which students become self-regulators of their own learning affects their academic success (Beishuizen \& Steffens, 2011; Lyn, Cuskelly, O’Callaghan, \& Grey, 2011; Zimmerman, 2008; Zimmerman \& Schunk, 2011). High self-regulated learners perform better than students with worse self-regulatory learning behavior (Artelt et al., 2010; Dresel \& Haugwitz, 2008). Moreover, students self-regulate, at the metacognitive, motivational, and behavioral levels, while they take an active role in their learning process (Dignath \& Büttner, 2008; Glenn, 2010; Kitsantas \& Zimmerman, 2009; Rosman, Mayer, \& Krampen, 2015; Zimmerman \& Labuhn, 2012). Thus, one aspect of self-regulated learning involves determination, since students must also be determined to use their cognitive and metacognitive strategies (Bilde, Vansteenkiste, \& Lens, 2011). Determined students perceive the learning task positively, make effort in it, and insist on it. This study involves self-determination as it is conceptualized in Self Determination Theory (SDT; Ryan, Williams, Patrick, \& Deci, 2009).

The concept of Self-Regulation in Self Determination Theory (Ryan et al., 2009) suggests that autonomy is an essential factor for achieving durable change. Based on the degree to which the regulation of an extrinsically motivated activity has been internalized and integrated, four different types of behavioral regulation have been identified: external regulation, introjected regulation, identified regulation, and integrated regulation (see Ryan et al., 2009). Although the benefits of intrinsic motivation in education have been supported (Lepper, Corpus, \& Iyengar, 2005; Miserandino, 1996; Otis, Grouzet, \& Pelletier, 2005; Ryan \& Connell, 1989; Vansteenkiste, Sierens, Soenens, Luyckx, \& Lens, 2009), this theory allows to examine how mixed or accompanying levels of extrinsic motivation would influence academic functioning and achievement (see Corpus \& Wormington, 2014; Deci \& Ryan, 2011; Guay, Ratelle, \& Chanal, 2008; Ratelle, Guay, Vallerand, Larose, \& Senécal, 2007; Wormington, Corpus, \& Anderson, 2012). In addition, the SDT lies within the perspective of the social construction 
of both metacognition and self-regulated learning (see Caprara, Vecchione, Alessandri, Gerbino, \& Barbaranelli, 2011; Efklides, 2014; Iiskala, Vauras, Lehtinen, \& Salonen, 2011; Volet, Summers, \& Thurman, 2009; Zimmerman \& Martinez-Ponz, 1990).

Metacognition is essential to self-regulated learning and both to successful learning (Bruning, Schraw, \& Norby, 2011; Rosman et al., 2015). However, to know the process and be able regulate the demands in a task, do not ensure success, the individual needs to want to, needs motive (Caprara, Fida, Vecchione, Del Bove, Vecchio, Barbaranelli, \& Bandura, 2008; Cera, Mancini, \& Antionietti, 2013; Benbenutty et al., 2014; Schunk \& Zimmerman, 2006; Smit, de Brabander, Boekaerts, \& Martens, 2017). Therefore, this study incorporates metacognition, self-regulated learning within a motivational perspective of Self Determination Theory, and self-beliefs, such as performance expectations, that are related to school functioning. Performance expectation is a sociocognitive construct of motivation included in the expectancy-value model of motivation (Eccles \& Wigfield, 2002). Previous research evident that high expectations for success are related to task engagement, persistence in carrying out tasks, effective use of cognitive and metacognitive strategies, and successful performance (Efklides, 2001; Lauermann, Eccles, \& Pekrun, 2017; Stephanou, 2008; 2012; Schunk \& Bursuck, 2016; Wigfield, Tonks, \& Klauda, 2009). On the other hand, high confidence in metacognitive abilities and self-regulation impact high expectancy beliefs (Schunk \& Zimmerman, 2008). Specifically, metacognitive process is a crucial factor of SLR and in predicting performance expectations and achievement in school (see Chatzistamatiou, Dermitzaki, Efklides, \& Leondari, 2013; Zimmerman \& Martinez-Pons, 1986). The aim of this research is to contribute to understand how these three constructs are related to one another and how they assist students to aware their weakness and strength to achieve their academic goals.

Most, of the previous researches examining the inter-correlations or inter-effects of the above concepts have focused on mathematics or/and language, while other school subjects have almost ignored, although features of the task affect learners' beliefs and, subsequent application, about skills and strategies are required, and competence and control beliefs (see Cromley \& Azevedo, 2011; Efklides, 2014; Kurman, 2001; Ommundsen, Haugen, \& Lund, 2005; Pressley \& Gaskins, 2006; Schunk \& Zimmerman, 2006; Wang \& Holcombe, 2010). This study focuses on language, mathematics and physical education.

This study also involved in fifth and sixth grades because few researches have examined metacognition and self-regulatory learning profiles in elementary school population and how both constructs interact with performance expectations, and subsequent school performance (see Nurmi \& Aunola, 2005; Patrick, Mantzicopoulos, Samarapungavan, \& French, 2008; Van der Stel \& Veenman, 2010). A developmental perspective is critical because the prevalence and optimal combination of the constructs may differ for elementary versus older students 
(see Artelt, Neuenhaus, Lingel, \& Schneider, 2012; Bakracevic-Vukman \& Licardo, 2010; Nicholls \& Miller, 1984; Schneider \& Lockl, 2006; Stipek \& MacIver, 1989; Weil, Fleming, Dumontheil, Kilford, Weil, Rees, \& Blakemore, 2013). In addition, the educational context typically in high school emphasizes an autonomy-supportive frame, antagonistic goals and is less supportive manner (Eccles \& Wigfield, 2000; Haselhuhn, Al-Mabuk, Gabriele, Groen, \& Galloway, 2007; Midgley, Anderman, \& Hicks, 1995; Stipek \& MacIver, 1989).

\subsection{Metacognition in Learning and Academic Achievement}

The template is used to format your paper and style the text. All margins, column widths, line spaces, and text fonts are prescribed; please do not alter them. You may note peculiarities. For example, the head margin in this template measures proportionately more than is customary. This measurement and others are deliberate, using specifications that anticipate your paper as one part of the entire journals, and not as an independent document. Please do not revise any of the current designations. Within the field of educational psychology, a great attempt has been dedicated to creating taxonomies that define and frame metacognition (e.g., Jacobs \& Paris, 1987; Krathwohl, 2002; Tarricone, 2011), developing respective measurements (e.g., Pintrich, Smith, Garcia, \& McKeachie, 1993; Schraw \& Dennison, 1994; Schraw \& Moshman, 1995; Sperling, Howard, Miller, \& Murphy, 2002), and examining the association of metacognition with academic achievement (e.g., Hacker et al., 2009; Pintrich, 2002; Zimmerman, 1990).

Flavell (1979) introduced the concept of metacognition which is defined as cognition about cognition. The early work of Flavell $(1976 ; 1978)$ and Brown (1978) and the more recent work of Brown (1987) and Schoenfeld (1987) suggest four constructs of metacognition, i.e., knowledge of cognition, regulation of cognition, beliefs about cognition, and awareness of cognition. Since then, have been efforts to synthesize and organize theory and research in metacognition, and its components are recognized to be metacognitive knowledge, metacognitive experiences and metacognitive skills/strategies (see Efklides, 2011; 2014; Jacobs \& Paris, 1987; Veenman, 2011; 2016; Young, 2010).

Metacognitive knowledge or metacognitive awareness refers to learner's knowledge about their personal strengths and weaknesses, pertains to a specific task, and may vary between tasks, strategies, goals, and other relevant to achievement of a pursuit goal information (Efklides, 2008; Perry, 2013; Tanner, 2012). There are three different types of meta-cognitive awareness, i.e., declarative knowledge, procedural knowledge, and conditional knowledge (Jacobs \& Paris, 1987).

Declarative knowledge concerns the knowledge about oneself as a learner and what factors influence his/her learning performance (Schraw \& Moshman, 1995; Schraw, Crippen, \& Hartley, 2006). It includes “individuals' knowledge of their affective states, including self-efficacy and motivation, and how these affect task performance" (Harris, Graham, Brindle, \& Sandmel, 2009: 133). Overall, this 
knowledge refers to self, task, and applicable strategies for achievement a specific task.

Procedural knowledge refers to one's knowledge about learning strategies and execution of procedural skills. Strategies might include "note-taking, slowing down for important information, skimming unimportant information, using mnemonics, summarizing main ideas and periodic self-testing" (Schraw et al., 2006: 114).

Conditional knowledge concerns a person's knowledge about when, where, and why to use certain cognitive actions or strategies (Flavell, 1979; Harris et al., 2009). In order to complete a pursuit task, students estimate the demands of the certain learning situation and select a particular procedure or the most appropriate strategies (Schraw et al., 2006).

Metacognitive experiences are "what the person is aware of and what she or he feels when coming across a task and processing information related to it" (Efklides, 2008).

Metacognitive skills/strategies are the "deliberate use of strategies (i.e. procedural knowledge) in order to control cognition" (Efklides, 2008). Metacognitive regulation refers to "metacognitive activities that help control one's thinking or learning” (Schraw \& Moshman, 1995: 354). Regulation of cognition consists of three essential components: planning, monitoring, and evaluating (Schraw, 1998; Tarricone, 2011; Veenman et al., 2006).

Planning activities include predicting, determining time and effort allocation, selecting strategies, setting goals and making plans of achievement those goals (Brown, 1987; Pintrich, 2004; Schraw et al., 2006; Schraw \& Moshman, 1995; Zimmerman, 2002). As Schraw and Moshman (1995) emphasize, the planning ability prior to get involved into a task may improve outcomes regardless of the context and content of the task.

Monitoring of cognition concern the awareness of comprehension and self-assessment during a learning situation (Schraw \& Moshman, 1995). It refers to period control of the proper use of the strategies applied to achieve a task (Cera et al., 2013). Specifically, it includes self-observation activities, and it concerns monitoring one's cognition, motivation, affect, task demands, time and need for help (Zimmerman, 2002). Through monitoring, learning can be controlled as the learners consider how they are completing the task and whether their selected strategy is working (Perry, 2013; Zimmerman, 2002). Learners, then, can make adjustments to their strategy, by basing upon their declarative, procedural, and conditional knowledge to readjust their learning (Schraw et al., 2006). Monitoring of cognition is of particular interest because students' self-awareness of their learning and subsequent monitoring can lead to improved understanding of content and problem-solving ability (Metcalfe, 2009; Serra \& Metcalfe, 2009; Schraw \& Moshman, 1995).

Evaluation of cognition "refers to appraising the products and regulatory processes of one's learning" (Schraw et al., 2006: 114). It is linked to the evalua- 
tion of the results achieved and the detection of the learner's reactions to these results. It is particularly related to planning of metacognitive regulation. When students evaluate their learning, they may ask themselves if they were to perform the certain learning activity again, they might act differently (Tarricone, 2011). Furthermore, they might consider planning differently, considering their strategies and the conditional factors that affected their achievement performance (Tanner, 2012).

Various researches have indicated the high importance of metacognition on academic achievement, since metacognition enables learners to control their own learning by setting goals and monitoring their progress (e.g., efficiently handle task demand and correct the weaknesses) in achievement them. Students with high metacognitive competencies, compared to students with less metacognitive competence, achieve higher performance (Artelt et al., 2010; Thillmann, 2008; Winne \& Nesbit, 2010). Furthermore, there is positive relationship between metacognition and learning objectives (Sungur \& Senler, 2009; Veenman et al., 2004), academic achievement and learning environment (Dimmitt \& McCormick, 2012; Dunlosky \& Metcalfe, 2009; Efklides, 2014; Hacker, Bol, \& Keener, 2008), writing and reading (Chonan \& Sawa, 2009; Harris, Santangelo, \& Graham, 2010), emotions in learning situations (Efklides, 2011; 2016; Karagiannides, Barboukis, Gourgoulis, Kosta, \& Antoniou, 2015) and problem solving (Antonietti, Ignazi, \& Perego, 2000).

Metacognitively aware learners are more strategic and perform better than unaware learners, allowing individuals to plan, sequence, and monitor their learning in a way that directly improves performance. Students with high metacognitive knowledge are: (a) able to adjust their own cognition and thinking to be more adaptive when solving problems; (b) more capable of transferring their knowledge of strategies to new learning situations; and (c) learn and perform better in the classroom than those who have little or no knowledge of cognition (Pintrich, 2002). Similarly, students who regulate their own learning and problem solving processes demonstrate superior academic functioning (e.g., placement into advanced level courses, high mathematics achievement test scores; Zimmerman, 1990), realize when they are effective learners and apply additional strategies to control or monitor their motivation (Alexander, 2008), superior performance on classroom tasks and assignments (Pintrich \& De Groot, 1990), and generally higher levels of academic performance (Gaskill \& Hoy, 2002).

The significance of the various components of metacognition in learning, however, may vary in elementary school students from older students, because metacognition is developmental in nature. Specifically, metacognitive knowledge starts in kindergarten and develops beyond adolescence over the entire lifespan (see Alexander \& Schwanenflugel, 1996; Artelt et al., 2012; Baker, 1989; Hasselhorn, 2006; Schneider, 2008; Schneider \& Lockl, 2006), as long as the educational processes continues to challenge the learner (Veenman et al., 2006). Concerning the development of metacognitive regulation, no major developmental trend has 
been identified (see Handel, Artelt, \& Weinert, 2013; Lockl \& Schneider, 2002; Schneider, 2008). Metacognitive skills appear at the age of 8 to 10 years, and expand in the years thereafter (Berk, 2003; Veenman \& Spaans, 2005; Veenman et al., 2004). In addition, planning matures earlier than both monitoring and evaluation (Veenman \& Spaans, 2005). Moreover, as Veenman et al. (2006: 8) suggest "metacognitive knowledge and skills already develop during preschool or early-school years at a very basic level, but become more sophisticated and academically oriented whenever formal educational requires the explicit utilization of a metacognitive repertoire".

\subsection{Self-Regulation in Learning from a Self-Determination Perspective and Academic Achievement}

The template is used to format your paper and style the text. All margins, column widths, line Self-regulated learning is a complex construct formed by different research traditions dealing with different terms and labels, which denote the same or at least strongly overlapping construct/s (see Dinsmore, Alexander, \& Loughlin, 2008). Self-regulated learning is partly defined by self-determination (Bilde et al., 2011) which is well conceptualized in Self-determination theory (Deci \& Ryan, 2002; 2012).

According to SDT (Deci \& Ryan, 2002; Ryan et al., 2009), individuals engage into various behaviors in order to satisfy the psychological needs for autonomy, competence and relatedness. This theory acknowledges a differentiation between autonomous or volitional and controlled or pressured motivation which have different effects, with autonomous motivation tending to be more effective across domains (Deci \& Ryan, 2008; Vansteenkiste, Simons, Lens, Sheldon, \& Deci, 2004). The three types of motivation, namely, intrinsic, extrinsic and amotivation, which account for the different reasons why a person engage in activities, lie on a continuum of self-determination (Deci \& Ryan, 2011).

Autonomy is an essential factor for achieving durable change. "Intrinsic motivation" is the prototype of self-determination. In this case, students are intrinsically motivated, interested in their studies, experience pleasure and satisfaction and enjoy learning (Niemiec \& Ryan, 2009).

When students do not develop or lost intrinsic interest in their studies, they are not motivated at all (amotivated) or extrinsically motivated for their school work. "Amotivation" represents the absence of motivation and thus is not self-determined. In extrinsic motivation, behaviors are impacted by external obligations and they separate from the activity itself (Ryan et al., 2009). SDT distinguishes among four types of external behavioral regulation depending on the extent of self-determined motivation, ranging from highly external to highly internal (Ryan \& Connell, 1989).

External regulation is the least self-determined form of extrinsic motivation, since students' behavior is controlled by external means, such as external authority, rewards or avoidance negative consequences (Niemiec \& Ryan, 2009; 
Ryan \& Deci, 2000a). A student, for example, might do study hard and do well just because he/she knows that he/she will be rewarded for this or because he /she thinks of being punished if he/she does not do so (Deci, Vallerand, Pelletier, \& Ryan, 1991; Taylor, Ntoumanis, Standage, \& Spray, 2010).

Introjected regulation refers to behavior which partially is taken in by the person, such as performing out to avoid feeling guilty or get ego-enhancements (Ryan \& Deci, 2000a; Ryan et al., 2009; Wininger \& DeSena, 2012). For example, a student studies before playing because he/she would feel guilty about not working first and playing later (Vansteenkiste, Lens, \& Deci, 2006).

Identified regulation, a more self-determined form of extrinsic motivation, refers to behavior which is positively endorsed and valued by the individual. In other words, identification is "the process of identifying with the value of an activity and accepting regulation of the activity as one's own" (Vansteenkiste et al., 2006: 21). For example, a student might study a certain task because its high importance in achieving his/her goals, despite difficulties or he/she may participate in classes because the good students do so (Ryan \& Deci, 2000a; 2006; Ryan et al., 2009; Standage, Duda, \& Ntoumanis, 2005).

Finally, intrinsic regulation, the highest level of self-determination, concerns a behavior which is perceived as being part of the self, and is undertaken for its own enjoyment.

Although Deci and Ryan (1985) included integrated regulation as the most self-determined form of extrinsic motivation in the continuum, it was excluded from this study because this regulation is mainly found in the adult population (Liu, Wang, Tan, Koh, \& Ee, 2009; Ryan et al., 2009).

Several studies evident that students who self-regulate their learning perform better and learn effectively than their counterparts with worse self-regulatory learning behavior (Artelt et al., 2010; Cleary \& Chen, 2009; Dresel \& Haugwitz, 2008; Jarvela \& Jarvenoja, 2011; Kistner, Rakoczy, \& Otto, 2010; Schunk \& Zimmerman, 2008; Zimmerman, 2008). Specifically, self-regulated students actively set goals and shift approaches flexibly (Wolters, 2011), apply appropriate learning strategies (Harris, Friedlander, Sadler, Frizzelle, \& Graham, 2005; Meltzer, 2007), monitor their performance by seeking feedback on it and making appropriate adjustments in the future (Harris et al., 2005), evaluate their academic progress (De Bruin, Thiede, \& Camp, 2011), seek out additional resources when needed to master content (Clarebout, Horz, \& Schnotz, 2010; De Bruin et al., 2011), pursuit positive learning environment and manipulate them to satisfy their needs (Kolovelonis, Goudas, \& Dermitzaki, 2011; Labuhn, Zimmerman, \& Hasselhorn, 2010), and have higher academic self-efficacy (Labuhn et al., 2010). Concerning the association of self-regulatory learning and self-efficacy beliefs, especially, research has shown they have reflexive positive impacts on one another, with higher self-efficacy beliefs increasing the use of self-regulation strategies which, in turn may enhance self-efficacy beliefs and academic achievement (see Pajares, 2008; Schunk \& Zimmerman, 2008). 
Regulatory learning styles influence affective, cognitive and behavioral functioning. Specifically, self-determined types of regulation (intrinsic motivation and identified regulation) and, mainly, autonomous motivation is related to several positive learning outcomes, such as effective cognitive processing, greater effort in the face of difficulties, more efficient time management, concentration and a positive experience during the activity, active participative and less defiant behaviour in the classroom, higher performance and higher grades (Barkoukis \& Hagger, 2009; Duncan, Hall, Wilson, \& Jenny, 2010; Reeve, 2002; Ryan \& Deci, 2000b; Taylor et al., 2010; Vallerand, 1997; Vansteenkiste, Zhou, Lens, \& Soenens, 2005). In contrast, when the students study due to external factors, they are more likely to drop-out and get low grades (Vansteenkiste et al., 2009). In a similar way, introjected regulation, although somehow contributes in academic engagement (Vansteenkiste, Simons, Lens, Soenens, \& Matos, 2005), it predicts maladaptive coping strategies and anxiety (Ryan \& Connell, 1989), and facilitates learning less than identified regulation (Assor, Vansteenkiste, \& Kaplan, 2009).

However, although intrinsic motivation has proved beneficial in elementary school, it is not clear how accompanying extrinsic motivation influence academic functioning and outcomes (Corpus \& Wormington, 2014). It is possible that elementary school students perceive external forces as helpful resources rather than as oppressive constraints, since their self-regulatory capabilities are under development (Bakracevic-Vukman \& Licardo, 2010; Cooper \& Corpus, 2009; Corpus, McClintic-Gilbert, \& Hayenga, 2009; Stipek, 2002) and autonomy is not yet significant component of their development (Beishuizen \& Steffens, 2011; Cole, Cole, \& Lightfoot, 2005; Erikson, 1968; Wray-Lake, Crouter, \& MacHale, 2010).

\subsection{Aim and Hypotheses of This Study}

This study aimed at examining: (a) students' metacognition with respect to both metacognitive knowledge: declarative, procedural and conditional, and metacognitive regulation: planning, monitoring, information management and evaluation; (b) students' self-regulated learning style regarding the four different types of behavioral regulation: external, introjected, identified and intrinsic; (c) the role of metacognition in self-regulated learning style, and in the impact of self-regulated learning style on performance expectations in the school subjects of language, mathematics and physical education; and (d) the role of metacognition in the interactive effect of self-regulated learning style and performance expectations on performance in the above school subjects.

The research hypotheses were the following:

Students' metacognition with respect to both knowledge and regulation will not be fully developed (Hypothesis 1a). There will be differences among the three components of metacognitive knowledge in favoring declarative (Hypothesis $1 \mathrm{~b}$ ). There will be differences among the four components of metacognitive regulation in least favoring evaluation (Hypothesis 1c).

Students will use a mixed profile of self-regulation when they get globally in- 
volved into school relate behaviors as well as when they do homework or do classwork or answer hard questions in class or try to do well in school (Hypothesis 2a). The relative strength of the four regulatory learning styles will vary across the four school related behaviors (Hypothesis 2b).

Metacognitive knowledge and, mainly, metacognitive regulation will have positive effects on self-regulated learning style (Hypothesis $3 \mathrm{a}$ ). The predictive strength of the components of metacognition of both metacognitive knowledge and metacognitive regulation will vary across the regulatory styles and within each regulatory style, with procedural knowledge and monitoring being in favoring (Hypothesis 3b).

Metacognition (mainly, metacognitive regulation) will positively influence the generation of school performance expectations in language, mathematics and physical education (Hypothesis 4a), and the positive effect of self-regulated learning styles (most, intrinsic) on performance expectations (Hypothesis $4 \mathrm{~b}$ ). The relative strength of predictors will differ across school subjects (Hypothesis 4c).

Metacognition (particularly, metacognitive regulation), self-regulated learning style (mainly, intrinsic) and, mainly, performance expectations will have positive effects on school performance in language, mathematics and physical education (Hypothesis 5a), metacognition will positively influence the interactive impact of self-regulated learning style and performance expectations on performance in the above school subjects (Hypothesis $5 b$ ). The relative strength of predictors will differ across the three school subjects (Hypothesis $5 \mathrm{c}$ ).

\section{Method}

\subsection{Participants}

A total of 243 students of both gender ( 122 boys, 121 girls), $5^{\text {th }}$ and $6^{\text {th }}$ grades, age from 11 to 12 years (Mean $=11.21$ years, $\mathrm{SD}=0.67$ years) participated into this investigation. The participants came, randomly, from 20 state primary schools of various regions of Greece. Students represent various parental socio-economical levels, with $35 \%, 40 \%$ and $15 \%$ of their parents having completed tertiary education, secondary education, and primary education, respectively.

In addition, 25 teachers, 14 females and 11 males, who teach the classes in question participated in the study. Their age ranged from 26 to 55 years, with average age of 43 years, S.D. $=5.9$. They reported teaching experience from 3 to 27 years with balance among years of teaching experience.

\subsection{Measures}

\subsubsection{Metacognition}

The Junior Metacognitive Awareness Inventory (Jr. MAI, Version B, Sperling et al., 2002) was used to measure students' metacognition, since this inventory was developed for use with learners in grades 6 through 9. The Jr. MAI, Version B, in consistence with Jacobs and Paris' (1987) theory, consists of the two subscales metacognitive knowledge and metacognitive regulation. Each subscale consists 
of nine Likert-scale items with response options ranging from 1 (never) to 5 (always). The participants circled the answer that best described the way they are when they are doing school work or home work. The metacognitive knowledge subscale measures: Declarative knowledge (e.g., "I know when I understand something"); Procedural knowledge (e.g., "I try to use ways of studying that have worked for me before"); and Conditional knowledge (e.g., "I use different learning strategies depending on the task"). The metacognitive regulation subscale measures five regulatory behaviors: Planning (e.g., "I decide what I need to get done before I start a task"); Monitoring (e.g., "I ask myself how well I am doing while I am learning something new"); Information management (e.g., "I focus on the meaning and significance of new information"); Evaluation (e.g., "When I am done with my schoolwork, I ask myself if I learned what I wanted to learn"); and Debugging which refers to correction of mistakes. For this study, debugging was included in monitoring of cognition. Also, in consistency with Sperling et al.'s study, an overall Jr. MAI mean score (MCT) was additionally calculated.

Cronbach's alphas were 0.76 for total metacognition, 0.67 for metacognition regulation and 0.60 for metacognitive knowledge. The values of Cronbach's alphas regarding subcomponents of metacognitive knowledge were also acceptable, ranging from 0.62 for procedural through 0.65 for conditional to 0.71 for declarative. In a similar way, Cronbach's alphas for metacognitive regulation were planning $=0.72$, monitoring $=0.75$, evaluation $=0.68$, and information management $=0.68$.

\subsubsection{Regulatory Learning Style}

The participants' regulatory learning style was measured via the Academic Self-Regulation Questionnaire (SRQ-A, Ryan \& Connell, 1989) which was designed for late elementary and middle school students. The scale concerns why students do various school related behaviors: Why do I do my homework? Why do I work on my classwork? Why do I try to answer hard questions in class? and Why do I try to do well in school? Each question is followed by eight several responses, ranging from $1=$ not true at all to $4=$ very true. They represent the 4 regulatory styles used in this scale: External regulation (e.g., "Because I'll get in trouble if I don't", "So that the teacher won't yell at me"); Introjected regulation (e.g., "Because I will feel really proud of myself if I do well”; "Because I feel ashamed of myself when I don't try"); Identified regulation (e.g., "Because it's important to me to try to answer hard questions in class", "Because it's important to me to work on my classwork"); and Intrinsic motivation (e.g., "Because I enjoy doing my homework", "Because I enjoy answering hard questions").

Cronbach's alphas were $0.75,0.57,0.78$ and 0.76 for external regulation, identified regulation, introjected regulation and intrinsic motivation, respectively.

\subsubsection{Performance Expectation}

A 4-item scale with separate versions for Mathematics, Language and Physical education was used to measure performance expectations. The construction of 
the scale was based on previous similar researches (e.g., Stephanou, 2008; 2012; Wigfield \& Cambria, 2010; Wigfield, Eccles, Fredricks, Simpkins, Roeser, \& Schiefele, 2015; Wigfield et al., 2009, for review). The wording of the questions for the three school subjects was the same except for the subject name (e.g., "How well do you think you will do on Language this school term?", "How well do you expect to do in Physical education this school term?"). Responses ranged from $1=$ very poorly to $5=$ excellent. Cronbach's alphas were $0.69,0.76$ and 0.64 for performance expectations in Language, Mathematics and Physical Education, respectively.

\subsubsection{School Performance}

Academic performance was the mean score of the term grades in the three school subjects that came from the school records, and of the teachers rating of their students' performance. The teachers were required to rate each of their students on a 4-item scale for performance in Mathematics, Language and Physical education (e.g. "Compared to other students, how good do you think she/he is in Language?", "How well does she/he do on Mathematics?"). Responses ranged from 1 = very poorly to $5=$ excellent. Cronbach's alphas were 0.92 in Language, 0.94 in Mathematics and 0.92 in Physical Education.

\subsubsection{Personal Information Scale for Both Groups of Participants}

The participants were requested demographic data including gender, grade level and age. In addition, teachers reported teaching experience, while students referred their parents' educational background.

\subsection{Procedure}

Permission to participate was obtained from each participating school and students' parents prior to administering the scales. The participants were provided written information about the aim of this study, and they were assured of anonymity and confidentiality.

In order to be adequate time for the participants to formulate impression about the examined variables, data were collected at the second school term of the total tree terms. The students completed the questionnaire individually, in quite classrooms, in front of the researcher, while the teachers completed the scales in their own free time in school. Teachers completed the school performance scale for each of their students separately.

To match the questionnaires that were responded by the same student, the students were asked to choose a code name and use it on all the scales they completed. The researcher matched the students with the school records and teachers' rating of their students for school performance.

\section{Results}

\subsection{Metacognitive Knowledge and Metacognitive Regulation}

The results from the repeated measure ANOVA, examining differences between 
the types of metacognitive knowledge, revealed significant effect, $F(2,240)=$ 83.30, $\eta^{2}=0.60$. Inspection of the mean scores on Table 1 and the post hoc pairwise comparisons showed that when the students are doing school work or home work they used metacognitive knowledge to a moderate extent, and that they predominately and least used declarative knowledge and procedural knowledge respectively.

The findings from repeated measures ANOVA, examining differences between the components of metacognitive regulation, showed significant effect, $\mathrm{F}(3,239)=25.74, \eta^{2}=0.24$. Post hoc pairwise comparisons and examination of the mean scores (Table 1 ) indicated that metacognitive regulation was a moderate level, and that when the students are doing school work or home work, they mainly apply planning, compared to any other component of metacognitive regulation, while evaluation was the least used.

Hypotheses $1 \mathrm{a}, 1 \mathrm{~b}$ and $1 \mathrm{c}$ were in the most confirmed by the above results.

\subsection{Self-Regulatory Learning Style}

In order to better understand the students' self-regulatory learning style, we examined it as a global factor across their four school related behaviors and within each of their four school behaviors. Specifically, first, we calculated the subscale score for each of the four subscales by averaging the items that make up that subscale. The four subscales are: external regulation, introjected regulation, identified regulation, and intrinsic motivation. Then, we calculated the subscale score for each of the regulatory styles within each school related behavior that is homework, classwork, effort to do well in school, and answer hard questions in class.

The results from repeated measures ANOVA with the four regulatory styles as within-subjects factor revealed that the students reported using a mixed profile of self-regulation when they globally involved into school relate behaviors (homework or classwork or trying to do well in school or answer hard questions

Table 1. Descriptive statistics for students' metacognitive knowledge and metacognitive regulation when they do school work or home work.

\begin{tabular}{clc}
\hline Components of metacognition & Mean & SD \\
\hline Declarative & \multicolumn{2}{c}{ Metacognitive knowledge } \\
Procedural & 4.27 & 0.59 \\
Conditional & 3.20 & 0.80 \\
& 4.09 & 0.62 \\
Planning & Metacognitive regulation \\
Monitoring & 4.06 & 0.80 \\
Information management & 3.82 & 0.73 \\
Evaluation & 3.72 & 0.78 \\
\hline
\end{tabular}


in class), $\mathrm{F}(3,239)=131.60, \eta^{2}=0.62$. Specifically, mean scores (Table 2$)$ and post hoc pairwise comparisons indicated that the students most often reported use of identified regulatory style than introjected regulatory style, and both external regulation and intrinsic motivation, in that order.

Four repeated measures ANOVAs, one for each school-related behavior (homework, schoolwork, effort to do well in school, oral performance in classes) in which regulatory styles was the within-subjects factor, showed significant effect of the regulatory styles in homework, $\mathrm{F}(3,239)=145, p<0.01, \eta^{2}=0.04$, in classwork, $\mathrm{F}(3,239)=16.10, p<0.01, \eta^{2}=0.04$, in effort to do well in school, $\mathrm{F}(3,239)$ $=112.70, p<0.01, \eta^{2}=0.25$, and in answer hard questions in class, $\mathrm{F}(3,239)=$ 25.55, $p<0.01, \eta^{2}=0.07$. Post hoc pairwise comparisons and the mean scores (Table 2) indicated the following findings within each school related behavior.

The findings regarding homework, demonstrated that the students tended towards self-determination, since they mainly used identified regulatory style than introjected regulation or, even less, both intrinsic motivation and external regulation.

In accordance with the findings in classwork, the students more utilized identified regulation than intrinsic motivation as well as they more used introjected regulation than extrinsic regulation. Moreover, the type of self-regulation style that was the least used in classwork was that of intrinsic motivation.

The result with respect to oral answer hard questions in class support that all types of motivation were applied in the following order from most to least: identified regulation, intrinsic motivation, external regulation and introjected regulation.

The findings regarding the overall school effort show that the students used the styles of self-regulation in the following order from most to least: identified regulation, introjected regulation, intrinsic motivation and external regulation.

The results from Anovas with students' school related behavior (homework/ classwork/effort to do well in school/answer hard questions in class) as between subjects factor and each of the regulatory styles as dependent variable showed significant effects in external regulation, $\mathrm{F}(3,239)=25.20, p<0.01, \eta^{2}=0.15$, in introjected regulation, $\mathrm{F}(3,239)=67.40, p<0.01, \eta^{2}=0.46$, in identified regulation, $\mathrm{F}(3,239)=46, p<0.01, \eta^{2}=0.17$, and in intrinsic motivation, $\mathrm{F}(3,239)=$ $35.45, p<0.01, \eta^{2}=0.15$. Post hoc pairwise comparisons and inspection of mean scores on Table 2 revealed that both intrinsic motivation and external regulation were applied in the following order from least to most: homework, classwork,

Table 2. Descriptive statistics for students' self-regulatory learning styles in their four school related behaviors.

\begin{tabular}{|c|c|c|c|c|c|c|c|c|c|c|}
\hline \multirow{2}{*}{ Self-regulatory learning style } & \multicolumn{2}{|c|}{ Homework } & \multicolumn{2}{|c|}{ Schoolwork } & \multicolumn{2}{|c|}{ Answer hard questions in class } & \multicolumn{2}{|c|}{ Overall school effort } & \multicolumn{2}{|c|}{ Global } \\
\hline & Mean & $\mathrm{SD}$ & Mean & SD & Mean & $\mathrm{SD}$ & Mean & $\mathrm{SD}$ & Mean & SD \\
\hline External regulation & 2.09 & 1.14 & 2.66 & 0.93 & 2.70 & 1.06 & 2.61 & 0.81 & 2.57 & 0.72 \\
\hline Introjected regulation & 3.09 & 0.62 & 2.79 & 0.90 & 2.60 & 0.82 & 3.20 & 0.61 & 2.93 & 0.58 \\
\hline Identified regulation & 3.29 & 0.70 & 2.87 & 1.06 & 3.12 & 0.70 & 3.60 & 0.64 & 3.22 & 0.50 \\
\hline
\end{tabular}


answer hard questions in class and effort to do well in school. In contrast, the students were most likely to use identified regulation in global effort to do well in school than in any other situation, and they were more likely to use this regulatory style in homework than in oral performance in class or in classwork. In a similar way, intrinsic motivation was most powerful style when students put effort to do well in school than when they do homework or classwork.

The above findings in the most confirmed Hypotheses $2 \mathrm{a}$ and $2 \mathrm{~b}$.

\subsection{Effects of Metacognition on self-Regulatory Learning Style}

Separate regression analyses, with the four components of metacognitive regulation and the three components of metacognitive knowledge as predictors of each of the global regulatory styles, revealed that both predictors had effects on the generation of the self-regulatory learning styles but their predictive strength varied across the regulatory styles and within each regulatory style. The higher the students' metacognition, particularly, metacognitive regulation, the higher their self-regulatory learning style, mainly, identified style. More precisely, the findings showed the following.

In external regulatory style, metacognitive regulation and metacognitive knowledge, together, negatively influenced its formulation, explaining $5.46 \%$ of the variance, $\mathrm{F}(7,235)=2.80, p<0.05$, but only monitoring of metacognitive regulation had unique and negative impact on it, beta $=-0.23, \mathrm{t}=-3.10, p<0.01$.

Concerning introjected regulation, the predictive model was found to be statistically significant, explaining $9 \%$ of the variance, $\mathrm{F}(7,235)=3.25, p<0.01$. However, only the information management of metacognitive regulation had positive contribution, beta $=0.22, \mathrm{t}=3.52, p<0.01$.

Identified regulation was found to be influenced by the two predictors, in combination, $\mathrm{R}^{2}=0.22, \mathrm{~F}(7,235)=9.55, p<0.01$. In addition, students who reported that they highly used procedural metacognitive knowledge, beta $=0.15, \mathrm{t}$ $=2.00, p<0.05$, highly used planning of metacognitive regulation, beta $=0.22, \mathrm{t}$ $=3.25, p<0.01$, and, particularly, highly used evaluating of metacognitive regulation, beta $=0.30, \mathrm{t}=4.60, p<0.01$, also reported frequent use of identified regulatory style.

The regulatory style of intrinsic motivation style was predicted by the two sets of concepts, $\mathrm{R}^{2}=0.13, \mathrm{~F}(7,235)=12.80, p<0.01$. The students who were high in evaluation of metacognitive regulation, beta $=0.14, \mathrm{t}=2.30, p<0.05$, and, mainly, in monitoring of metacognitive regulation, beta $=0.25, \mathrm{t}=3.85, p<0.01$, were more likely to be intrinsically self-regulating.

Hypotheses $3 \mathrm{a}$ and $3 \mathrm{~b}$ were partly confirmed by the above results.

\subsection{The Role of Metacognition and Self-Regulatory Learning Style on Performance Expectations in Language, Mathematics and Physical Education}

In order to examine the role of students' metacognition and self-regulatory styles in the formulation of their school term performance expectations in language, 
mathematics and physical education, and the role of metacognition on the impact of self-regulatory styles on performance expectations, three separate hierarchical regression analyses were performed. Regulatory styles and metacognition (metacognitive knowledge and metacognitive regulation) were entered in first and second step of the analysis, respectively. The results from these analyses revealed that, while metacognitive knowledge, metacognitive regulation and self-regulated styles accounted in the variance in performance expectations, their relative power in influencing it varied across the school subjects and within each school subject. More accurately, the findings are the following:

In language: (a) metacognition and self-regulatory styles, together, proved positive influential factor of performance expectations, $\mathrm{R}^{2}=0.18, \mathrm{~F}(11,231)=$ $4.80, p<0.01$; (b) the components of metacognitive knowledge and metacognitive regulation, as a group, enhanced the impact of self-regulatory styles on performance expectations, $\mathrm{R}^{2} \mathrm{ch}=0.076, \mathrm{Fch}(7,231)=3.50, p<0.01$; (c) external regulation, beta $=-0.24, \mathrm{t}=3.00, p<0.01$, declarative metacognitive knowledge, beta $=0.16, \mathrm{t}=2.40, p<0.05$, and, mainly, introjected self-regulated learning style, beta $=0.31, \mathrm{t}=3.75, p<0.01$, accounted for a significant variability in performance expectation.

In mathematics: (a) metacognition and self-regulatory styles, together, had significant effect on performance expectation, $\mathrm{R}^{2}=0.19, \mathrm{~F}(11,231)=5.10, p<$ 0.01; (b) metacognitive knowledge and metacognitive regulation, in combination, had direct effect on performance expectation, beyond that of self-regulatory styles, $\mathrm{R}^{2} \mathrm{ch}=0.14, \mathrm{Fch}(7,231)=5.07, p<0.01$; (c) introjected self-regulated learning style, beta $=0.20, \mathrm{t}=2.45, p<0.05$, information management of metacognitive regulation, beta $=0.14, \mathrm{t}=2.30, p<0.05$, declarative metacognitive knowledge, beta $=0.17, \mathrm{t}=2.45, p<0.05$, and, mostly, conditional metacognitive knowledge, beta $=0.22, \mathrm{t}=3.00, p<0.01$, positively contributed into generation of performance expectations.

In physical education: (a) metacognition and self-regulatory styles, together, had positive effect on performance expectations, explaining a low amount of its variability, $\mathrm{R}^{2}=0.06, \mathrm{~F}(11,231)=2.55, p<0.05$; (b) metacognition had indirect impact on performance expectation through regulatory styles, $\mathrm{R}^{2} \mathrm{ch}=0.017$, $\operatorname{Fch}(7,231)=1.00, p>0.05$; (c) identified self-regulatory learning style was a solo positive contributor of it, beta $=0.25, \mathrm{t}=3.08, p<0.01$.

The above findings partly confirmed Hypotheses $4 \mathrm{a}, 4 \mathrm{~b}$ and $4 \mathrm{c}$.

\subsection{Effects of Metacognition, Self-Regulatory Learning Style and Performance Expectations on School Performance in Lan- guage, Mathematics and Physical Education}

The results from hierarchical regression analyses, with school performance as predicted variable and performance expectations (entering into first step of the analysis), self-regulatory style (entering into second step of the analysis) and metacognition-knowledge and regulation (entering into third step of the analysis) as predictor variables, revealed that the three sets of predictors had comple- 
mentary and positive consequences for school performance but their predictive strength varied across the school subjects and within each school subject.

In language: (a) the three concepts, as a group, explained a moderate amount of the variance of school performance, $\mathrm{R}^{2}=0.22, \mathrm{~F}(12,230)=5.50, p<0.01$; (b) the impact of performance expectations on performance was to a significant extent mediated by self-regulatory styles, $\mathrm{R}^{2} \mathrm{ch}=0.052, \mathrm{Fch}(4,237)=3.80, p<0.01$; (c) metacognition, globally, had indirect effect, through the interaction of performance expectations and self-regulatory styles, $\mathrm{R}^{2} \mathrm{ch}=0.052, \mathrm{Fch}(7,230)=$ $1.70, p>0.05$; and (d) performance expectations, compared to other predictors, was the most powerful positive factor of school performance, beta $=0.29, \mathrm{t}=$ $4.52, p<0.01$, followed by introjected self-regulatory style, beta $=0.24, \mathrm{t}=2.90$, $p<0.01$, and declarative knowledge, beta $=0.13, \mathrm{t}=2.00, p<0.05$, while external regulatory style was a negative contributor of performance, beta $=-0.24, \mathrm{t}=$ $-3.00, p<0.01$.

In mathematics: (a) all the predictors, as a group, positively influenced school performance, $\mathrm{R}^{2}=0.29, \mathrm{~F}(12,230)=8.20, p<0.01$; (b) self-regulatory styles enhanced the effects of performance expectations on performance, revealing its direct effect on it, $\mathrm{R}^{2} \mathrm{ch}=0.07, \mathrm{Fch}(4,237)=5.40, p<0.01$; (c) metacognition influenced performance via the interaction of performance expectations and self-regulatory styles, $\mathrm{R}^{2} \mathrm{ch}=0.038, \mathrm{Fch}(7,230)=1.76, p>0.05$; (d) performance expectations was the most powerful positive formulator of performance, beta $=$ $0.40, \mathrm{t}=6.65, \mathrm{p}<0.01$, followed by introjected self-regulatory style, beta $=0.23, \mathrm{t}$ $=2.93, p<0.01$, and procedural metacognitive knowledge, beta $=0.14, \mathrm{t}=2.65$, $p<0.05$, while external regulation accounted for a significant and negative variability in performance, beta $=-0.25, \mathrm{t}=-3.45, p<0.01$.

In physical education: (a) the three concepts, in combination, explained a small amount of the variability of school performance, $\mathrm{R}^{2}=0.095, \mathrm{~F}(12,230)=$ 2.20, $p<0.05$; (b) both self-regulatory styles, $\mathrm{R}^{2} \mathrm{ch}=0.022, \mathrm{Fch}(4,237)=1.35$, $p>0.05$, and metacognition, $\mathrm{R}^{2} \mathrm{ch}=0.043, \mathrm{Fch}(7,230)=1.54, p>0.05$, had indirect effect on performance; and (c) performance expectations positively contributed to performance, $\mathrm{b}=0.18, \mathrm{t}=2.90, p<0.01$, while external regulatory style accounted for a negative variability in it, $\mathrm{b}=-15, \mathrm{t}=1.95, p<0.05$.

The above findings partly confirmed Hypotheses $5 \mathrm{a}$ and $4 \mathrm{~b}$, while they totally confirmed Hypothesis $5 c$.

\section{Discussion}

This study, within a self-determination perspective, examined metacognition and self-regulation, and their interactive role in performance expectations and performance in mathematics, language and physical education in elementary school.

\subsection{Metacognition}

As expected, students referred to moderate use of metacognitive knowledge in 
doing school work or homework, showing that metacognitive knowledge develops beyond elementary school (Artelt et al., 2012; Schneider, 2008). Also, in accordance with previously reported data (e.g., Gourgey, 2010; Martini \& Shore, 2008), and literature about the development of the components of metacognitive knowledge (e.g., Lockl \& Schneider, 2002), declarative knowledge and procedural knowledge was most and least mentioned by the students, respectively.

In consistency with the notion that regulation of cognition develops slowly and might not be completely operative even in adults (Lai, 2011; Van der Stel \& Veenman, 2014; Veenman \& Spaans, 2005; Weil et al., 2013), students reported moderate use of metacognitive regulation in doing school work or home work. This specific finding, on one hand, reflects young students' difficulties at planning, directing and evaluating their behavior within a learning task (see Goswami, 2015; Lockl \& Schneider, 2002), and, on the other hand, indicates the necessity of enhancing them, since the actual and conscious regulation of the learning process is through metacognitive regulation, that is, the implementation of metacognitive knowledge in the process of self-regulated learning (see Flavell, 1979; Schneider \& Artelt, 2010). In a similar way, confirming our hypotheses, students mainly applied planning, probably, because planning matures earlier than monitoring and evaluation (see Veenman, 2011; Veenman et al., 2006). In line with the latter finding and previous researches (Handel et al., 2013), students applied evaluation least. This specific finding might also be an evidence that students had not been asked to evaluate their own achievement behavior, although self-feedback is essential component of effective learning and transfer (Bransford, Brown, \& Cocking, 2000; Schraw, 1998).

The moderate level of both metacognitive regulation and metacognitive knowledge might also result from a lack of emphasis on metacognition in most classrooms (see Eccles \& Roeser, 2011), although achieving awareness of one's own cognition and how to regulate it at the primary years is a major factor in school functioning (Goswami, 2015). Previous researches indicate the adults' crucial role in supporting children's metacognitive knowledge, especially procedural (Robson, 2016), and their metacognitive regulation (Mevarech \& Fridkin, 2006). This is also in line with Efklides (2014), supporting that metacognition is socially shared and constructed.

The moderate level of metacognition could be also associated with the self-report measure of Jr.MAI. Literature suggest that learners may not be consciously aware of their cognition, although they apply metacognitive strategies (Lai, 2011; Schraw, 2009; Schraw \& Moshman, 1995). More research needs to specify such issues.

\subsection{Self-Regulatory Learning Style}

The findings regarding regulatory learning style are mainly in line with our expectation and SDT. Students reported an inclination towards a self-determined profile but with elements of no self-determination, when they did the various 
school-related behaviors. More accurately, students mainly applied identified regulatory learning style in do homework or do classwork or try to answer hard questions in class or try to do well in school. This result is in line with the self-determination theory and research evidence (e.g., Lewis \& Vialleton, 2011), suggesting that when an individual identifies with an action (e.g., when the activity has a personal meaning for the student) or the value the action represents, she/he approves of it personally and in this way identifications are concurrent with a high degree of perceived autonomy. The students, probably, valued school-related activities highly, and, simultaneously, tried to satisfy their parents' high expectations for school achievement. The age of the participants might be an additional exploratory factor to this finding, since, within SDT, intrinsic motivation reflects growth-oriented tendency, and elementary school student have not yet achieved autonomy (see Artelt et al., 2012; Bakracevic-Vukman \& Licardo, 2010; Wigfield, Klauda, \& Cambria, 2011). Also, the context of the primary education is supportive to the students, resulting in the certain regulatory learning styles (see Haselhuhn et al., 2007).

As far as intrinsic self-regulatory learning style is concerned, it was reported as the second often used in trying to answer hard question. This finding could be expected since that situation is person-oriented. Intrinsic motivation was also most employed in conditions linked to the students' overall effort to do well in school, reflecting its crucial role in achieving long-term goals (see Schunk \& Bursuck, 2016). This finding is also in line with previous studies showing that intrinsic motivation for the value of schoolwork is the main predicting factor of behaviors linked to self-regulated learning (Van der Veen \& Peetsman, 2009). However, intrinsic motivation was the least used style in classwork, while introjected regulation was the second most often used regulatory style, suggesting that successful classroom learning, at this certain age, is significantly depends on teachers' support (Reeve \& Jang, 2006). What is more, these findings are in agreement with the theory of self-determination, according to which the satisfaction of needs for competence, relatedness and autonomy results in the reinforcement of individual self-determination and this leads them to more frequent participation in a given activity (Ryan \& Deci, 2000b).

\subsection{Effects of Metacognition on Self-Regulatory Learning Style}

The findings regarding the impact of metacognition on regulatory learning style were in the main as expected. The students who were high metacognitive learners were more likely to develop self-determined learning styles which facilitate learning (see Alexander, 2008; Efklides, 2011). More precisely, metacognition explained a greater amount of the variance of the identified regulatory learning style than of the rest of the styles, complementing the significance of metacognition in gaining autonomy learning behavior, and, parallelly, the social construction of both metacognition and regulatory learning behavior, at least, at elementary school (see Efklides, 2014; Veenman et al., 2004; Rosman et al., 2015). 
The relative power of the components of metacognition in predicting regulatory style varied across the four regulatory learning styles, and within each regulatory learning style. Specifically, metacognitive regulation, compare to metacognitive knowledge, was a more powerful formulator of regulatory learning styles, mainly the self-determinative of intrinsic and identified, highlighting its crucial role in the process of self-regulated learning (see Flavell, 1979; Schneider \& Artelt, 2010). This finding also hind that metacognitive knowledge and metacognitive relation share variance each other, supporting relevant literature (Efklides, 2011). Compared to the rest of the components of metacognitive regulation, evaluation and monitoring proved to be the best positive predictor of identified learning style and intrinsic learning style, respectively. This result suggests that, when significant others, such as teachers and parents, encourage students to think and evaluate their own learning behavior in a learning task, the students perceive the specific task as valuable and enjoyable (see Chatzistamatiou et al., 2013; Schunk \& Bursuck, 2016). Regarding the components of metacognitive knowledge, only procedural knowledge had a positive contribution into identified regulatory learning style, showing its determinant role in regulatory learning style. Research is needed to clarify under which conditions and tasks metacognitive knowledge affects regulation styles.

\subsection{The Role of Metacognition and Self-Regulatory Learning Style in Performance Expectations and School Performance}

The results of this study are congruent with the literature (e.g., Cera et al., 2013; Schunk \& Zimmerman, 2008; Tobias \& Everson, 2009), revealing positive moderate correlations of metacognition with school performance expectations and school performance in mathematics, language and physical education. However, metacognition explained a small percentage of variance of both performance expectations, beyond self-regulatory style, and performance, beyond the interactive effect of performance expectations and regulatory learning style, in both language and mathematics, while it had no significant unique contribution in physical education. More precisely, in language, performance expectation and performance were only predicted by declarative knowledge. In mathematics, performance expectation was affected by information management, declarative knowledge and, particularly conditional knowledge, while performance was predicted by procedural knowledge.

The above findings suggest that high metacognitive regulation learners perceived autonomy strategies as more effective and implied them to regulate their motivation (see Alexander, 2008). In turn, such an autonomous or towards autonomous regulatory learning style positively influenced performance expectations and performance across the three school subjects. On the contrary, metacognitive knowledge was not a powerful predictor of regulatory learning style, and, hence, it accounted in school achievement directly. Further research, however, is needed to examine this suggestion. 
The above results also complemented Efklides and Vlachopoulos's (2012) suggestion that metacognitive awareness of strategies does not sufficiently explain cognitive processing outcomes. As Efklides (2014) proposes, it is important to examine the various cognitive, affective and motivational strategies that students apply for regulating their learning in various learning domains. For example, students' knowledge, perceptions of the task-difficulty, perceptions of self-efficacy might influence performance expectations and performance, as literature suggests (e.g., Benbenutty et al., 2014; Cera et al., 2013; Cromley \& Azevedo, 2011; Schunk \& Zimmerman, 2006; Smit et al., 2017; Stephanou, 2008). The Jr. MAI might be another influential factor of these findings, as the extent of correlations between metacognition and academic indicators depends considerably on how metacognition is assessed, with favoring the content-task specific method (Tobias \& Everson, 2009; Young \& Fry, 2008). The emphasis of the elementary school in mathematics and language than other school subjects, such as physical education, might be an additive explanatory factor for the lack of the direct effect of metacognition in physical education. Research is needed to specify such a speculation.

In line with Self-determination theory (Deci \& Ryan, 2002), and previous researches (e.g., Boekaerts \& Corno, 2005; Smit et al., 2017), the present results revealed that the degree of self-determination to which the students involved in school related-behaviors predicted their performance expectations and school performance across the tree school subjects. It is interesting, however, that, although students mainly reported identified regulation, introjected regulation accounted for a greater variance in performance expectations, and it played a partial explanatory role in the impact of performance expectations on school performance in both language and mathematics. It seems that students, at this certain educational level, perceived, to a considerable extent, their teachers or parents' controlling behavior as beneficial for their goals in these two major school subjects (see Corpus \& Wormington, 2014). On the contrary, in physical education, supporting research evidence (e.g., Ntoumanis, 2001; Standage, Duda, \& Ntoumanis, 2003), introjected regulation had no effect on any outcome variable, while performance expectations was only predicted by identified regulation, reflecting, thus, students' their own enjoyment of this learning task, and significant others' low controlling behavior.

Also, in accordance to previous studies (see Corpus \& Wormington, 2014) and SDT, external regulation had negative contribution in school performance across the three school subjects as well as in performance expectation in language. Finally, against previous researches and SDT, intrinsic regulation had no exploratory role in performance expectation and performance in language, mathematic and physical education. The age of the students may be related to this finding, given that pre-adolescents are still developing their self-regulatory capabilities, and autonomy are under development (Bakracevic-Vukman \& Licardo, 2010; Cooper \& Corpus, 2009; Erikson, 1968; Stipek, 2002; Wray-Lake et al., 2010). 


\section{Conclusion and Suggestions for Future Research}

This study documents some central aspects of thinking and learning in the primary years.

Metacognition was reported to a moderate level of use. Teachers and parents should concern not only about what students learn but also about how they learn it.

Particular metacognitive constructs influenced the generation of self-regulated learning style. Research needs to identify and delineate these constructs further, in order to help teachers to promote students' self-regulation in their learning. Certain metacognitive constructs were also formulator factors of performance expectations and performance, mainly in mathematics, with no effect in physical education. Further research is needed on domain of specific metacognition.

The relative strength of the four regulatory learning styles in each of the school related-activity and across the three school subjects suggest their unique and complementary effect in successful learning. On the other hand, external regulation proved negative contributor in school performance. Consequently, it is important to facilitate students to develop autonomous regulatory learning style along with satisfaction of their needs of relatedness and competence. The role of parents and teachers would be helpful regarding improvement in motivation level and learning process.

Performance expectations predicted performance. Further research needs about how expectancies associate with various motivational, emotional and behavioral outcomes in various age groups of children, and how they are influenced by different school contexts.

An issue in this study concerns the nature of self-report scales. Future research might use multi-method research designs, such as objective measures, reflection-in-action and reflection-on-action methods, to better understand the complex processes that examined in this study.

\section{References}

Alexander, J. M., \& Schwanenflugel, P. J. (1996). Development of Metacognitive Concepts about Thinking in Gifted and Nongifted Children: Recent Research. Learning and Individual Differences, 8 , 305-325.

Alexander, P. A. (2008). Why This and Why Now? Introduction to the Special Issue on Metacognition, Self-Regulation, and Self-Regulated Learning. Educational Psychology Review, 20, 369-372. https://doi.org/10.1007/s10648-008-9089-0

Antonietti, A., Ignazi, S., \& Perego, P. (2000). Metacognitive Knowledge about Problem-Solving Methods. British Journal of Educational Psychology, 70, 1-16. https://doi.org/10.1348/000709900157921

Artelt, C., Naumann, J., \& Schneider, W. (2010). Lesemotivation und Lernstrategien. In E. Klieme, C. Artelt, J. Hartig, N. Jude, O. Köller, M. Prenzel, W. Schneider, \& P. Stanat (Eds.), PISA 2009. Bilanz nach einem Jahrzehnt (pp. 73-112). [Motivation for Reading and Learning Strategies]. Münster, Germany: Waxmann.

Artelt, C., Neuenhaus, N., Lingel, K., \& Schneider, W. (2012). Entwicklung und wechsel- 
seitige: Effekte von metakognitiven und bereichsspezifischen. Wissenskomponenten in der Sekundarstufe. [Development of Metacognitive and Domain-Specific Knowledge and Their Mutual Effects in Secondary School]. Psychologische Rundschau, 63, 18-25. https://doi.org/10.1026/0033-3042/a000106

Assor, A., Vansteenkiste, M., \& Kaplan, A. (2009). Identified and Introjection Approach and Introjection Avoidance Motivations in School and in Sport: The Limited Benefits of Self-Worth Strivings. Journal of Educational Psychology, 101, 482-497. https://doi.org/10.1037/a0014236

Baker, L. (1989). Metacognition, Comprehension Monitoring, and the Adult Reader. Educational Psychology Review, 1, 3-38. https://doi.org/10.1007/BF01326548

Bakracevic-Vukman, K., \& Licardo, M (2010). How Cognitive, Metacognitive, Motivational and Emotional Self-Regulation Influence School Performance in Adolescence and Early Adulthood. Educational Studies, 36, 259-268. https://doi.org/10.1080/03055690903180376

Barkoukis, V., \& Hagger, M. S. (2009). A Test of the Trans-Contextual Model of Motivation in Greek High School Pupils. Journal of Sport Behavior, 32, 152-174.

Beishuizen, J., \& Steffens, K. (2011). A Conceptual Framework for Research on Self-Regulated Learning. In R. Carneiro, P. Lefrere, K. Steffens, \& J. Underwood (Eds.), Self-regulated Learning in Technology Enhanced Learning Environments: A European Perspective. Rotterdam: Sense Publishers. https://doi.org/10.1007/978-94-6091-654-0_1

Benbenutty, H., Cleary, T. J., Kitsantas, A. (2014). Applications of Self-Regulated Learning across Diverse Disciplines. Charlotte, NC: Information Age Publishing, Inc.

Berk, L. E. (2003). Child Development (6th ed.). Boston: Allyn and Bacon.

Bilde, J., Vansteenkiste, M., \& Lens, W. (2011). Understanding the Association between Future Time Perspective and Self-Regulated Learning through the Lens of Self-Determination Theory. Learning and Instruction, 21, 332-344. https://doi.org/10.1016/j.learninstruc.2010.03.002

Boekaerts, M., \& Corno, L. (2005). Self-Regulation in the Classroom: A Perspective on Assessment and Intervention. Applied Psychology: An International Review, 54, 199-231. ttps://doi.org/10.1111/j.1464-0597.2005.00205.x

Bransford, J. D., Brown, A. L., \& Cocking, R. R. (2000). How People Learn: Brain, Mind, Experience, and School. Washington DC: National Academy Press.

Brown J. M. (1998). Self-Regulation and the Addictive Behaviours, In W. R., Miller, \& N. Heather (Eds.), Treating Addictive Behaviors (2nd ed., pp. 61-73). New York: Plenum Press.

Brown, A. L. (1978). Knowing When, Where, and How to Remember: A Problem of Metacognition. Advances in Instructional Psychology, 1, 77-165.

Brown, A. L. (1987). Metacognition, Executive Control, Self-Regulation, and Other More Mysterious Mechanisms. In F. E. Weinert, \& R. Kluwe (Eds.), Metacognition, Motivation, and Understanding (pp. 65-116). Hillsdale: L. Erlbaum Associates.

Bruning, R. H., Schraw, G. J., \& Norby, M. M. (2011). Cognitive Psychology and Instruction (5th ed.). Boston, MA: Pearson.

Caprara, G. V., Fida, R., Vecchione, M., Del Bove, G., Vecchio, G. M., Barbaranelli, C., \& Bandura, A. (2008). Longitudinal Analysis of the Role of Perceived Self-Efficacy for Self-Regulated Learning in Academic Continuance and Achievement. Journal of Educational Psychology, 100, 525-534. https://doi.org/10.1037/0022-0663.100.3.525

Caprara, G. V., Vecchione, M., Alessandri, G., Gerbino, M., \& Barbaranelli, C. (2011). The Contribution of Personality Traits and Self-Efficacy Beliefs to Academic Achieve- 
ment: A Longitudinal Study. British Journal of Educational Psychology, 81, 78-96. https://doi.org/10.1348/2044-8279.002004

Carr, M. (2010). The Importance of Metacognition for Conceptual Change and Strategy Use in Mathematics. In H. S. Waters, \& W. Schneider (Eds), Metacognition, Strategy Use, \& Instruction (pp. 176-197). London: The Guildford Press.

Cera, R., Mancini, M., \& Antionietti, A. (2013). Relationships between Metacognition, Self-Efficacy and Self-regulation in Learning. Journal of Educational, Cultural and Psychological Studies, 7, 115-141.

Chatzistamatiou, M., Dermitzaki, I. (2013). Teaching Mathematics with Self-Regulation and for Self-Regulation: Teachers' Reports. Hellenic Journal of Psychology, 10, 253-274.

Chatzistamatiou, M., Dermitzaki, I., Eflides, A., \& Leondari, A. (2013). Motivational and Affective Determinants of Self-Regulatory Strategy Use in Elementary School Mathematics. Educational Psychology: An International Journal of Experimental Education Psychology, 35, 835-850. https://doi.org/10.1080/01443410.2013.822960

Chonan, H., \& Sawa, T. (2009). A Perspective on the Role of Metacognition in Reading by Students with Hearing Impairments: A Review. Japanese Journal of Special Education, 47, 163-171.

Clarebout, G., Horz, H., \& Schnotz, W. (2010). The Relations between Self-Regulation and the Embedding of Support in Learning Environments. Educational Technology Research and Development, 58, 573-587. https://doi.org/10.1007/s11423-009-9147-4

Cleary, T. J., \& Chen, P. P. (2009). Self-Regulation, Motivation, and Math Achievement in Middle School: Variations across Grade Level and Math Context. Journal of School Psychology, 47, 291-314. https://doi.org/10.1016/j.jsp.2009.04.002

Cole, M., Cole, S. R., \& Lightfoot, C. (2005). The Development of Children. New York: Worth Publishers.

Cooper, C. A., \& Corpus, J. H. (2009). Learners' Developing Knowledge of Strategies for Regulating Motivation. Journal of Applied Developmental Psychology, 30, 525-536. https://doi.org/10.1016/j.appdev.2008.12.032

Corpus, J, H., \& Wormington, S. V. (2014). Profiles of Intrinsic and Extrinsic Motivations in Elementary School: A Longitudinal Analysis. The Journal of Experimental Education, 82, 480-501. https://doi.org/10.1080/00220973.2013.876225

Corpus, J. H., McClintic-Gilbert, M. S., \& Hayenga, A. (2009). Within-Year Changes in Children'S Intrinsic and Extrinsic Motivational Orientations: Contextual Predictors and Academic Outcomes. Contemporary Educational Psychology, 34, 154-166. https://doi.org/10.1016/j.cedpsych.2009.01.001

Cromley, J., \& Azevedo, R. (2011). Measuring Strategy Use in Context with Multiple-Choice Items. Metacognition and Learning, 6, 155-177.

https://doi.org/10.1007/s11409-011-9070-z

de Bruin, A. B., Thiede, K. W., \& Camp, G. (2011). Generating Keywords Improves Metacomprehension and Self-Regulation in Elementary and Middle School Children. Journal of Experimental Child Psychology, 109, 294-310. https://doi.org/10.1016/j.jecp.2011.02.005

De la Fuente, J., Zapata, L., Martínez-Vicente, J. M., Sander, P., \& Cardelle-Elawar, M. (2015). The Role of Personal Self-Regulation and Regulatory Teaching to Predict Motivational-Affective Variables, Achievement, and Satisfaction: A Structural Model. Frontiers in Psychology, 6, 399.

Deci, E. L., \& Ryan, R. M (2008). Self-Determination Theory: A Macrotheory of Human Motivation, Development, and Health. Canadian Psychology, 49, 182-185. 
https://doi.org/10.1037/a0012801

Deci, E. L., \& Ryan, R. M. (1985). Intrinsic Motivation and Self-Determination in Human Behavior. New York: Plenum. https://doi.org/10.1007/978-1-4899-2271-7

Deci, E. L., \& Ryan, R. M. (2002). Handbook of Self-determination Research. Rochester, NY: University Rochester Press.

Deci, E. L., \& Ryan, R. M. (2011). Self-Determination Theory. In P. A. M. V. Lange, A. W. Kruglanski, \& E. T. Higgins (Eds.), Handbook of Theories of Social Psychology: Volume 1 (pp. 416-437). Thousand Oaks, CA: SAGE.

Deci, E. L., \& Ryan, R. M. (2012). Motivation, Personality, and Development within Embedded Social Contexts: An Overview of Self-Determination Theory. In R. M. Ryan (Ed.), Oxford Handbook of Human Motivation (pp. 85-107). Oxford: Oxford University Press.

Deci, E. L., Vallerand, R. J., Pelletier, L. G., \& Ryan R. M. (1991). Motivation and Education: The Self-Determination Perspective. The Educational Psychologist, 26, 325-346. https://doi.org/10.1080/00461520.1991.9653137

Dignath, C., \& Büttner, G. (2008). Components of Fostering Self-Regulated Learning among Students. A Meta-Analysis on Intervention Studies at Primary and Secondary School Level. Metacognition and Learning, 3, 231-264.

https://doi.org/10.1007/s11409-008-9029-X

Dimmitt, C., \& McCormick, C. B. (2012). Metacognition in Education. In K. R. Harris, S. Graham, \& T. Urdan (Eds.), APA Educational Psychology Handbook (Vol. 1, pp. 157-187). Washington, DC: APA. https://doi.org/10.1037/13273-007

Dinsmore, D. L., Alexander, P. A., \& Loughlin, S. M. (2008). Focusing the Conceptual Lens on Metacognition, Self-Regulation, and Self-Regulated Learning. Educational Psychology Review, 20, 391-409. https://doi.org/10.1007/s10648-008-9083-6

Dresel, M., \& Haugwitz, M. (2008). A Computer-Based Training Approach to Foster Motivation and Self-Regulated Learning. Journal of Experimental Education, 77, 3-20. https://doi.org/10.3200/JEXE.77.1.3-20

Duncan, L. R., Hall, C. R., Wilson, P. M., \& Jenny, O. (2010). Exercise Motivation: A Cross-Sectional Analysis Examining Its Relationships with Frequency, Intensity, and Duration of Exercise. International Journal of Behavioral Nutrition and Physical Activity, 7, 7. https://doi.org/10.1186/1479-5868-7-7

Dunlosky, J., \& Metcalfe, J. (2009). Metacognition. Thousand Oaks, CA: Sage.

Eccles, J. S., \& Roeser, R. W. (2011). Schools as Developmental Contexts during Adolescence. Journal of Research on Adolescence, 21, 225-241. https://doi.org/10.1111/j.1532-7795.2010.00725.x

Eccles, J. S., \& Wigfield, A. (2000). Schooling Influence on Motivation and Achievement. In S. Danziuger, \& J. Waldfogel (Eds.), Securing the Future: Investing in Children from Birth to College (pp. 153-181). New York: Sage.

Eccles, J. S., \& Wigfield, A. (2002). Motivational Beliefs, Values and Goals. Annual Review of Psychology, 53, 109-132. https://doi.org/10.1146/annurev.psych.53.100901.135153

Efklides, A. (2001). Metacognitive Experiences in Problem Solving: Metacognition, Motivation, and Self-Regulation. In A. Efklides, J. Kuhl, \& R. M. Sorrentino (Eds.), Trends and Prospects in Motivation Research (pp. 297-323). Dordrecht: Kluwer Academic Publishers. https://doi.org/10.1007/0-306-47676-2

Efklides, A. (2008). Metacognition: Defining Its Facets and Levels of Functioning in Relation to Self-Regulation and co-Regulation. European Psychologist, 13, 277-287. 
https://doi.org/10.1027/1016-9040.13.4.277

Efklides, A. (2011). Interactions of Metacognition with Motivation and Affect in Self-Regulated Learning: The MASRL Model. Educational Psychologist, 46, 6-25. https://doi.org/10.1080/00461520.2011.538645

Efklides, A. (2014). How Does Metacognition Contribute to the Regulation of Learning? An Integrative Approach. Psychological Topics, 23, 1-30.

Efklides, A. (2016). Affect and Metacognition: Why Their Interactions Are Important for $S R L$. Keynote Speech at the 15th ICM. Greece, Thessaloniki.

Efklides, A., \& Vlachopoulos, S. P. (2012). Measurement of Metacognitive Knowledge of Self, Task, and Strategies in Mathematics. European Journal of Psychological Assessment, 28, 227-239. https://doi.org/10.1027/1015-5759/a000145

Erikson, E. H. (1968). Identity: Youth and crisis. New York: Norton.

Flavell, J. H. (1976). Metacognitive Aspects of Problem Solving. In L. B. Resnick (Ed.), The Nature of Intelligence (pp. 231-235). Hillsdale, NJ: Lawrence Erlbaum Associates.

Flavell, J. H. (1978). Metacognitive Development. In J. M. Scandura, \& C. J. Brainerd (Eds.), Structural/Process Theories of Complex Human Behavior (pp. 213-245). Alphenaan den Rijn: Sijthoff and Noordhoff.

Flavell, J. H. (1979). Metacognition and Cognitive Monitoring: A New Area of Cognitive-Developmental Inquiry. American Psychologist, 34, 906-911. https://doi.org/10.1037/0003-066X.34.10.906

Flavell, J. H. (1987). Speculations about the Nature and Development of Metacognition. In F. Weinert, \& R. Kluwe (Eds.), Metacognition, Motivation and Understanding (pp. 21-29). Hillsdale, NJ: Erlbaum.

Gaskill, P. J., \& Hoy, A. W. (2002). Self-Efficacy and self-regulated Learning: The Dynamic Duo in School Performance. In J. Aronson (Ed.), Improving Academic Achievement: Impact of Psychological Factors on Education (pp. 185-208). San Francisco: Academic Press.

Glenn, D. (2010). How Students Can Improve by Studying Themselves. Chronicle of Higher Education. http://chronicle.com/article/Struggling-Students-Can-Imp/64004/

Gomes, C. M. A., Golino, H. F., \& Menezes, I. G. (2014). Predicting School Achievement Rather than Intelligence: Does Metacognition Matter? Psychology, 5, 1095-1110. https://doi.org/10.4236/psych.2014.59122

Goswami, U. (2015). Children's Cognitive Development and Learning. Cambridge: Cambridge Primary Review Trust.

Gourgey, A. (2010). Metacognition in Basic Skills Instruction. In H. J. Hartman (Ed.), Metacognition in Learning and Instruction (pp. 17-32). New York: Springer.

Guay, F., Ratelle, C. F., \& Chanal, J. (2008). Optimal Learning in Optimal Contexts: The role of Self-Determination in Education. Canadian Psychology, 49, 233-240. https://doi.org/10.1037/a0012758

Hacker, D. J., Bol, L., \& Keener, M. C. (2008). Metacognition in Education: A Focus on Calibration. In J. Dunlosky, \& R. Bjork (Eds.), Handbook of Memory and Metacognition (pp. 411-455). Mahwah, NJ: Lawrence Erlbaum Associates.

Hacker, D. J., Dunlosky, J., \& Graesser, A. C. (2009). Handbook of Metacognition in Education. New York: Routledge.

Handel, M., Artelt, C., \& Weinert, S. (2013). Assessing Metacognitive Knowledge: Development and Evaluation of a Test Instrument. Journal for Educational Research, 5, 162-188. 
Händel, M., Artelt, C., \& Weinert, S. (2013). Assessing Metacognitive Knowledge: Development and Evaluation of a Test Instrument. Journal for Educational Research Online, 5, 162-188.

Harris, K. R., Friedlander, B. D., Saddler, B., Frizzelle, R., \& Graham, S. (2005). Self-Monitoring of Attention versus Self-Monitoring of Academic Performance: Effects among Students with ADHD in the General Education Classroom. Journal of Special Education, 39, 145-156. https://doi.org/10.1177/00224669050390030201

Harris, K. R., Graham, S., Brindle, M., \& Sandmel, K. (2009). Metacognition and Children's Writing. In D. Hacker, J. Dunlosky, \& A. Graesser (Eds.), Handbook of Metacognition in Education (pp. 131-153). Mahwah, NJ: Lawrence Erlbaum.

Harris, K. R., Santangelo, T., \& Graham, S. (2010). Metacognition and Strategies Instruction in Writing. In H. S. Waters, \& W. Schneider (Eds.), Metacognition, Strategy Use, and Instruction (pp. 227-255). New York: The Guilford Press.

Haselhuhn, C. W., Al-Mabuk, R., Gabriele, A., Groen, M., \& Galloway, S. (2007). Promoting Positive Achievement in the Middle School: A Look at Teachers' Motivational Knowledge, Beliefs, and Teaching Practices. Research in Middle Level Education, 30, $1-20$.

Hasselhorn, M. (2006). Metakognition. In D. H. Rost (Ed.), Handwörterbuch Pädagogische Psychologie (2nd ed., pp. 466-471). [Metacognition]. Weinheim: Beltz PVU.

Iiskala, T., Vauras, M., Lehtinen, E., \& Salonen, P. (2011). Socially Shared Metacognition within Primary School Pupil Dyads' Collaborative Processes. Learning and Instruction, 21, 379-393.

Jacobs, J. E., \& Paris, S. G. (1987). Children's Metacognition about Reading: Issues in Definition, Measurement, and Instruction. Educational Psychologist, 22, 225-278. https://doi.org/10.1080/00461520.1987.9653052

Jarvela, S., \& Jarvenoja, H. (2011). Socially Constructed Self-Regulated Learning and Motivation Regulation in Collaborative Learning Groups. Teachers College Record, 113, 350-374.

Karagiannides, Y., Barboukis, V., Gourgoulis, V., Kosta, G., \& Antoniou, P. (2015). The Role of Motivation and Metacognition on the Development of Cognitive and Affective Responses in Physical Education Lessons: A Self-Determination Approach. Motricidade, 11, 135-150.

Kistner, S., Rakoczy, K., \& Otto, B. (2010). Promotion of Self-Regulated Learning in Classrooms: Investigating Frequency, Quality, and Consequences for Student Performance. Metacognition and Learning, 5, 157-171. https://doi.org/10.1007/s11409-010-9055-3

Kitsantas, A., \& Zimmerman, B. J. (2009). College students' Homework and Academic Achievement: The Mediating Role of Self-Regulatory Beliefs. Metacognition and Learning, 4, 1556-1623. https://doi.org/10.1007/s11409-008-9028-y

Kolovelonis, A., Goudas, M., \& Dermitzaki, I. (2011). The Effect of Different Goals and Self-Recording on Self-Regulation of Learning a Motor Skill in a Physical Education Setting. Learning and Instruction, 21, 355-364.

Kostaridou-Efklides, A. (2011). Metacognitive Procedure and Self-Regulation [In Greek,

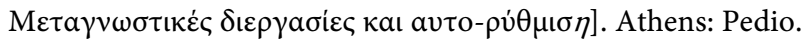

Krathwohl, D. R. (2002). A Revision of Bloom's Taxonomy: An Overview. Theory into Practice, 41, 221-218. https://doi.org/10.1207/s15430421tip4104_2

Kurman, J. (2001). Self-Enhancement: Is it Restricted to individualistic Cultures? Personality and Social Psychology Bulletin, 27, 1705-1716. 
https://doi.org/10.1177/01461672012712013

Labuhn, A. S., Zimmerman, B. J., \& Hasselhorn, M. (2010). Enhancing Students' Self-Regulation and Mathematics Performance: The Influence of Feedback and Self-Evaluative Standards. Metacognition and Learning, 5, 173-194.

https://doi.org/10.1007/s11409-010-9056-2

Lai, E. R. (2011). Metacognition: A Literature Review. Pearson Assessments Research Reports.

Lauermann, F., Eccles, J. S., \& Pekrun, R. (2017). Why Do Children Worry about their Academic Achievement? An Expectancy-Value Perspective on Elementary Students' Worries about Their Mathematics and Reading Performance. International Journal on Mathematics Education, 49, 339-354. https://doi.org/10.1007/s11858-017-0832-1

Lepper, M. R., Corpus, J. H., \& Iyengar, S. S. (2005). Intrinsic and Extrinsic Motivational Orientations in the Classroom: Age Differences and Academic Correlates. Journal of Educational Psychology, 97, 184-196. https://doi.org/10.1037/0022-0663.97.2.184

Lewis, T., \& Vialleton, E. (2011). The Notions of Control and Consciousness in Learner Autonomy and Self-Regulated Learning: A Comparison and Critique. Innovation in Language Learning and Teaching, 5, 205-219. https://doi.org/10.1080/17501229.2011.577535

Liu, W. C., Wang, C. K. J., Tan, O. S, Koh, C, \& Ee, J. (2009). A Self-Determination Approach to Understanding Students' Motivation in Project Work. Learning and Individual Differences, 19, 139-145.

Lockl, K., \& Schneider, W. (2002). Developmental Trends in Children's Feeling-of-Knowing Judgements. International Journal of Behavioral Development, 26, 327-333. https://doi.org/10.1080/01650250143000210

Lyn, L., Cuskelly, M., O’Callaghan, M., \& Grey, P. (2011). Self-Regulation: A New Perspective on Learning Problems Experienced by Children Born Extremely Preterm. Australian Journal of Educational \& Developmental Psychology, 11, 1-10.

Martini, R., \& Shore, B. M. (2008). Pointing to Parallels in Ability-Related Differences in the Use of Metacognition in Academic and Psychomotor Tasks. Learning and Individual Differences, 18, 237-247.

Meltzer, L. (2007). Executive Function in Education: From Theory to Practice. New York: The Guilford Press.

Metcalfe, J. (2009). Metacognitive Judgments and Control of Study. Current Directions in Psychological Science, 18, 159-163. https://doi.org/10.1111/j.1467-8721.2009.01628.x

Mevarech, Z., \& Fridkin, S. (2006). The Effects of Improve on Mathematical Knowledge, Mathematical Reasoning and Meta-Cognition. Metacognition and Learning, 1, 85-97. https://doi.org/10.1007/s11409-006-6584-x

Midgley, C., Anderman, E., \& Hicks, L. (1995). Differences between Elementary and Middle School Teachers and Students: A Goal Theory Approach. Journal of Early Adolescence, 15, 90-113. https://doi.org/10.1177/0272431695015001006

Miserandino, M. (1996). Children Who Do Well in School: Individual Differences in Perceived Competence and Autonomy in Above-Average Children. Journal of Educational Psychology, 88, 203-214.

Nicholls, J. G., \& Miller, A. T. (1984). Reasoning about the Ability of Self and Others: A Developmental Study. Child Development, 55, 1990-1999. https://doi.org/10.2307/1129774

Niemiec, C. P., \& Ryan, R. M. (2009). Autonomy, Competence, and Relatedness in the Classroom: Applying Self-Determination Theory to Educational Practice. Theory and 
Research in Education, 7, 133-144. https://doi.org/10.1177/1477878509104318

Ntoumanis, N. (2001). A Self-Determination Approach to the Understanding of Motivation in Physical Education. British Journal of Educational Psychology, 71, 225-242. https://doi.org/10.1348/000709901158497

Nurmi, J., \& Aunola, K. (2005). Task-Motivation during the First School Years: A Person-Oriented Approach to Longitudinal Data. Learning and Instruction, 15, 103-122

Ommundsen, Y., Haugen, R., \& Lund, T. (2005). Academic Self-Concept, Implicit Theories of Ability, and Self-Regulation Strategies. Scandinavian Journal of Educational Research, 49, 461-474. https://doi.org/10.1080/00313830500267838

Otis, N., Grouzet, F. M. E., \& Pelletier, L. G. (2005). Latent Motivational Change in an Academic Setting: A 3-Year Longitudinal Study. Journal of Educational Psychology, 97, 170-183.

Pajares, F. (2008). Motivational Role of Self-Efficacy Beliefs in Self-Regulated Learning. In D. H. Schunk, \& B. J. Zimmerman (Eds.), Motivation and Self-Regulated Learning: Theory, Research and Applications (pp. 111-139). New York: Erlbaum.

Panadero, E. (2017). A Review of Self-Regulated Learning: Six Models and Four Directions for Research. Frontiers in Psychology, 8, 422. https://doi.org/10.3389/fpsyg.2017.00422

Patrick, H., Mantzicopoulos, P., Samarapungavan, A., \& French, B. F. (2008). Patterns of Young Children's Motivation for Science and Teacher-Child Relationships. Journal of Experimental Education, 76, 121-144. https://doi.org/10.3200/JEXE.76.2.121-144

Perry, B. (2013). Metacognitive Awareness: Impact of a Metacognitive Intervention in a Pre-Nursing Course. Ph.D Thesis, Baton Rouge, Louisiana: Louisiana State University.

Pintrich, P (2002). The Role of Metacognitive Knowledge in learning, Teaching, and Assessing. Theory into Practice, 41, 219-226. https://doi.org/10.1207/s15430421tip4104_3

Pintrich, P. R. (2004). A Conceptual Framework for Assessing Motivation and Self-Regulated Learning in College Students. Educational Psychology Review, 16, 385-407. https://doi.org/10.1007/s10648-004-0006-X

Pintrich, P. R., \& De Groot, E.V. (1990). Motivational and Self-Regulated Learning Components of Classroom Academic Performance. Journal of Educational Psychology, 82, 33-40. https://doi.org/10.1037/0022-0663.82.1.33

Pintrich, P. R., Smith, D., Garcia, T., \& McKeachie, W. (1993). Predictive Validity and Reliability of the Motivated Strategies for Learning Questionnaire (MSLQ). Educational and Psychological Measurement, 53, 801-813. https://doi.org/10.1177/0013164493053003024

Pressley, M., \& Gaskins, I. W. (2006). Metacognitively Competent Reading Comprehension Is Constructively Responsive Reading: How Can Such Reading Be Developed in Students? Metacognition and Learning, 1, 99-113. https://doi.org/10.1007/s11409-006-7263-7

Puustinen, M., \& Pulkkinen, L. (2001). Models of Self-Regulated Learning: A Review. Scandinavian Journal of Educational Research, 45, 269-286. https://doi.org/10.1080/00313830120074206

Ratelle, C. F., Guay, F., Vallerand, R. J., Larose, S., \& Senécal, C. (2007). Autonomous, Controlled, and Amotivated Types of Academic Motivation: A Personoriented Analysis. Journal of Educational Psychology, 99, 734-746.

https://doi.org/10.1037/0022-0663.99.4.734

Reeve, J. (2002). Self-Determination Theory Applied to Educational Settings. In E. L. Deci, \& R. M. Ryan (Eds.), Handbook on Self-Determination Research: Theoretical and 
Applied Issues. Rochester, NY: University of Rochester Press.

Reeve, J., \& Jang, H. (2006). What Teachers Say and Do to Support Students' Autonomy during a Learning Activity. Journal of Educational Psychology, 98, 209-219. https://doi.org/10.1037/0022-0663.98.1.209

Robson, S. (2016). Self-Regulation, Metacognition and Child- and Adult-Initiated Activity: Does It Matter Who Initiates the Task? Journal Early Child Development and Care, 186, 764-784. https://doi.org/10.1080/03004430.2015.1057581

Rosman, T., Mayer, A., \& Krampen, G. (2015). Combining Self-Assessments and Achievement Tests in Information Literacy Assessment: Empirical Results and Recommendations for Practice. Assessment \& Evaluation in Higher Education, 40, 740-754. https://doi.org/10.1080/02602938.2014.950554

Ryan, R. M., \& Connell, J. P. (1989). Perceived Locus of Causality and Internalization: Examining Reasons for Acting in Two Domains. Journal of Personality and Social Psychology, 57, 749-761. https://doi.org/10.1037/0022-3514.57.5.749

Ryan, R. M., \& Deci, E. L. (2000a). Self-Determination Theory and the Facilitation of Intrinsic Motivation, Social Development, and Well-Being. American Psychologist, 55, 68-78. https://doi.org/10.1037/0003-066X.55.1.68

Ryan, R. M., \& Deci, E. L. (2000b). Intrinsic and Extrinsic Motivations: Classic Definitions and New Directions. Contemporary Educational Psychology, 25, 54-67.

Ryan, R. M., \& Deci, E. L. (2006). Self-regulation and the Problem of Human Autonomy: Does Psychology Need Choice, Self-Determination, and Will? Journal of Personality, 74, 1557-1585. https://doi.org/10.1111/j.1467-6494.2006.00420.x

Ryan, R. M., Williams, G. C., Patrick, H., \& Deci, E. L. (2009). Self-Determination Theory and Physical Activity: The Dynamics of Motivation in Development and Wellness. Hellenic Journal of Psychology, 6, 107-124.

Schneider, W. (2008). The Development of Metacognitive Knowledge in Children and Adolescents: Major Trends and Implications for Education. Mind, Brain, and Education, 2, 114-121. https://doi.org/10.1111/j.1751-228X.2008.00041.x

Schneider, W., \& Artelt, C. (2010). Metacognition and Mathematics Education. The International Journal on Mathematics Education, 42, 149-161. https://doi.org/10.1007/s11858-010-0240-2

Schneider, W., \& Lockl, K. (2006). Entwicklung metakognitiver Kompetenzen im Kindes-und Jugendalter. [Development of Metacognitive Ability in Children and Adolescents]. In W. Schneider, C. F. Graumann, N. Birbaumer, \& B. Sodian (Eds.), Enzyklopädie der Psychologie: Entwicklungspsychologie (Vol. 2., pp. 721-767). Göttingen: Hogrefe.

Schoenfeld, A. H. (1987). What's All the Fuss about Metacognition? In A. H. Schoenfeld (Ed.), Cognitive Science and Mathematics Education (pp. 189-215). Hillsdale, New Jersey: Lawrence Erlbaum Associates.

Schraw, G. (1998). Promoting General Metacognitive Awareness. Instructional Science 26, 113-125. https://doi.org/10.1023/A:1003044231033

Schraw, G. (2009). Measuring Metacognitive Judgments. In D. J. Hacker, J. Dunlosky, \& A. C. Graesser (Eds.), The Educational Psychology Series. Handbook of Metacognition in Education (pp. 415-429). New York: Routledge.

Schraw, G., \& Dennison, R. S. (1994). Assessing Metacognitive Awareness. Contemporary Educational Psychology, 19, 460-475. https://doi.org/10.1006/ceps.1994.1033

Schraw, G., \& Moshman, D. (1995). Metacognitive Theories. Educational Psychology Review, 7, 351-371. https://doi.org/10.1007/BF02212307

Schraw, G., Crippen, K. J., \& Hartley, K. (2006). Promoting Self-Regulation in Science 
Education: Metacognition as Part of a Broader Perspective on Learning. Research in Science Education, 36, 111-139. https://doi.org/10.1007/s11165-005-3917-8

Schunk, D. H., \& Zimmerman, B. J. (2006). Competence and Control Beliefs: Distinguishing the Means and Ends. In P. A. Alexander, \& P. H. Winne (Eds.), Handbook of Educational Psychology (2nd ed., pp. 349-367). Mahwah, NJ: Lawrence Erlbaum Associates.

Schunk, D. H., \& Zimmerman, B. J. (2008). Motivation and Self-Regulated Learning: Theory, Research, and Applications. New York: Taylor \& Francis Group, LLC.

Schunk, D., \& Bursuck, W. (2016). Self-Efficacy, Agency and Volition: Student' Beliefs and Reading Motivation. In P. Afflerbach (Ed.), Handbook of Individual Differences in Reading: Reader, Text, and Context (pp. 54-66). London: Routledge.

Serra, M. J., \& Metcalfe, J. (2009). Effective Implementation of Metacognition. In D. J. Hacker, J. Dunlosky, \& A. C. Graesser (Eds.), Metacognition in Educational Theory and Practice (pp. 278-298). Mahwah, New Jersey: Lawrence Erlbaum Associates, Inc.

Smit, K., de Brabander, C. J., Boekaerts, M., \& Martens, R. L. (2017). The Self-Regulation of Motivation Motivational Strategies as Mediator between Motivational Beliefs and Engagement for Learning. International Journal of Educational Research, 82, 124-134. https://doi.org/10.1016/j.ijer.2017.01.006

Sperling, R. A., Howard, B. C., Miller, L. A., \& Murphy, C. (2002). Measures of Children'S Knowledge and Regulation of Cognition. Contemporary Educational Psychology, 27, 51-79. https://doi.org/10.1006/ceps.2001.1091

Standage, M., Duda, J. L., \& Ntoumanis, N. (2003). A Model of Contextual Motivation in Physical Education: Using Constructs from Self-Determination and Achievement Goal Theories to Predict Physical Activity Intentions. Journal of Educational Psychology, 95, 97-110. https://doi.org/10.1037/0022-0663.95.1.97

Standage, M., Duda, J. L., \& Ntoumanis, N. (2005). A Test of Self-Determination Theory in School Physical Education. British Journal of Educational Psychology, 75, 411-433. https://doi.org/10.1348/000709904X22359

Stephanou, G. (2008). Students' Value Beliefs, Performance Expectations, and School Performance: The Effect of School Subject and Gender. Hellenic Journal of Psychology: The Journal of the Psychological Society of Northern Greece, 5, 231-257.

Stephanou, G. (2012). Students' School Performance in Language and Mathematics: Effects of Hope on Attributions, Emotions and Performance Expectations. International Journal of Psychological Studies, 4, 92-119. https://doi.org/10.5539/ijps.v4n2p93

Stipek, D. (2002). Motivation to Learn: From Theory to Practice (4th ed.). Needham Heights, MA: Allyn \& Bacon.

Stipek, D. J., \& MacIver, D. (1989). Developmental Change in Children's Assessment of Intellectual Competence. Child Development, 60, 521-538.

https://doi.org/10.2307/1130719

Sungur, S., \& Şenler, B. (2009). An Analysis of Turkish High School Students' Metacognition and Motivation. Educational Research and Evaluation, 15, 45-62. https://doi.org/10.1080/13803610802591667

Tanner, K. D. (2012). Feature Approaches to Biology Teaching and Learning Promoting Student Metacognition. CBE-Life Sciences Education, 11, 113-120. https://doi.org/10.1187/cbe.12-03-0033

Tarricone, P. (2011). The Taxonomy of Metacognition. New York: Taylor \& Francis Group.

Taylor, I. M., Ntoumanis, N., Standage, M., \& Spray, C. M. (2010). Motivational Predic- 
tors of Physical Education Students' Effort, Exercise Intentions, and Leisure-Time Physical Activity: A Multilevel Linear Growth Analysis. Journal of Sport \& Exercise Psychology, 32, 99-120. https://doi.org/10.1123/jsep.32.1.99

Thillmann, H. (2008). Selbstreguliertes lernen durch experimentieren: Von der erfassung zur förderung. [Self-Regulated Learning through Experimentation: From Acquisition to Promotion]. Doctoral dissertation, Universität Duisburg-Essen, Fakultät für Bildungswissenschaften, Institut für Psychologie, Lehr-Lernpsychologie.

Tobias, S., \& Everson, H. T. (2009). Metacognition and Children'S Writing. In D. J. Hacker, J. Dunlosky, \& A. C. Graesser (Eds.), Metacognition in Educational Theory and Practice (pp. 107-126). Mahwah, New Jersey: Lawrence Erlbaum Associates, Inc.

Vallerand, R. J. (1997). Toward a Hierarchical Model of Intrinsic and Extrinsic Motivation. In M. P. Zanna (Ed.), Advances in Experimental Social Psychology (Vol. 29, pp. 271-360). New York: Academic Press.

Van der Stel, M., \& Veenman, M. (2010). Development of Metacognitive Skillfulness: A Longitudinal Study. Learning and Individual Differences, 20, 220-224.

Van der Stel, M., \& Veenman, M. V. J. (2014). Metacognitive Skills and Intellectual Ability of Young Adolescents: A Longitudinal Study from a Developmental Perspective. European Journal of Psychology of Education, 29, 117-137. https://doi.org/10.1007/s10212-013-0190-5

Van der Veen, I., \& Peetsman, T. (2009). The Development of Self-Regulated Learning Behavior of First-Year Students in the Lowest Level of Secondary School in the Netherlands. Learning and Individual Differences, 19, 34-46.

Vansteenkiste, M., Lens, W., \& Deci, E. L. (2006). Intrinsic versus Extrinsic Goal-Contents in Self-Determination Theory: Another Look at the Quality of Academic Motivation. Educational Psychologist, 41, 19-31.

https://doi.org/10.1207/s15326985ep4101_4

Vansteenkiste, M., Sierens, E., Soenens, B., Luyckx, K., \& Lens, W. (2009). Motivational Profiles from a Self-Determination Perspective: The Quality of Motivation Matters. Journal of Educational Psychology, 101, 671-688. https://doi.org/10.1037/a0015083

Vansteenkiste, M., Simons, J., Lens, W., Sheldon, K. M., \& Deci, E. L. (2004). Motivating Learning, Performance, and Persistence: The Synergistic Effects of Intrinsic Goal Contents and Autonomy-Supportive Contexts. Journal of Personality and Social Psychology, 87, 246-260. https://doi.org/10.1037/0022-3514.87.2.246

Vansteenkiste, M., Simons, J., Lens, W., Soenens, B., \& Matos, L. (2005). Examining the Impact of Extrinsic Versusintrinsic Goal Framing and Internally Controlling versus Autonomy-Supportive Communication Style upon Early Adolescents' Academic Achievement. Child Development, 76, 483-501.

Vansteenkiste, M., Zhou, M., Lens, W., \& Soenens, B. (2005). Experiences of Autonomy among Chinese Learners: Vitalizing or Immobilizing? Journal of Educational Psychology, 97, 468-483. https://doi.org/10.1037/0022-0663.97.3.468

Veenman, M. V. J. (2011). Learning to Self-Monitor and Self-Regulate. In R. Mayer, \& P. Alexander (Eds.), Handbook of Research on Learning and Instruction (pp. 197-218). New York: Routledge.

Veenman, M. V. J. (2016). Metacognition. In P. Afflerbach (Ed.), Handbook of Individual Differences in Reading: Reader, Text, and Context (pp. 26-40). London: Routledge.

Veenman, M. V. J., \& Spaans, M. A. (2005). Relation between Intellectual and Metacognitive Skills: Age and Task. Learning and Individual Differences, 15, 159-176.

Veenman, M. V. J., van Hout-Wolters, B. H. A. M., \& Afflerbach, P. (2006). Metacogni- 
tion and Learning: Conceptual and Methodological Considerations. Metacognition and Learning, 1, 3-14. https://doi.org/10.1007/s11409-006-6893-0

Veenman, M. V. J., Wilhelm, P., Beishuizen, J. J., \& Beishuizen, J. J. (2004). The Relation between Intellectual and Metacognitive Skills from a Developmental Perspective. Learning and Instruction, 14, 89-109.

Volet, S., Summers, M., \& Thurman, J. (2009). High-Level Co-Regulation in Collaborative Learning: How does It Emerge and How Is It Sustained? Learning and Instruction, 19, 128-143.

Wang, M. T., \& Holcombe, R. (2010). Adolescents' Perceptions of School Environment, Engagement, and Academic Achievement in Middle School. American Educational Research Journal, 47, 633-662. https://doi.org/10.3102/0002831209361209

Weil, L. G., Fleming, S. M., Dumontheil, I., Kilford, E. J., Weil, R. S., Rees, G., \& Blakemore, S. (2013). The Development of Metacognitive Ability in Adolescence. Consciousness and Cognition, 22, 264-271.

Wigfield, A., \& Cambria, J. (2010). Students’ Achievement Values, Goal Orientations, and Interest: Definitions, Development, and Relations to Achievement Outcomes. Developmental Review, 30, 1-35.

Wigfield, A., Eccles, J. S., Fredricks, J. A., Simpkins, S., Roeser, R., \& Schiefele, U. (2015). Development of Achievementmotivation and Engagement. In R. M. Lerner (Series Ed.), \& M. Lamb (Vol. Ed.), Handbook of Child Psychology and Developmental Science, Vol. 3: Socioemotional Processes (7th ed., pp. 657-700). Hoboken, NJ: Wiley.

Wigfield, A., Klauda, S. L., \& Cambria, J. (2011). Influences on the Development of Academic Self-Regulatory Processes. In B. J. Zimmerman, \& D. H. Schunk (Eds.), Handbook of Self-Regulation of Learning and Performance (pp.33-48). New York: Routledge.

Wigfield, A., Tonks, S., \& Klauda, S. L. (2009). Expectancy-Value Theory. In: K. R. Wentzel, \& A. Wigfield (Eds), Handbook of Motivation in School (pp. 55-76). New York: Routledge Taylor Francis Group.

Wininger, S. R., \& DeSena, T. M. (2012). Comparison of Future Time Perspective and Self-Determination Theory for Explaining Exercise Behavior. Journal of Applied Biobehavioral Research, 17, 109-128. https://doi.org/10.1111/j.1751-9861.2012.00081.x

Winne, P. H., \& Nesbit, J. C. (2010). The Psychology of Academic Achievement. Annual Review of Psychology, 61, 653-678.

https://doi.org/10.1146/annurev.psych.093008.100348

Wolters, C. A. (2011). Regulation of Motivation: Contextual and Social Aspects. Teachers College Record, 113, 265-283.

Wormington, S. V., Corpus, J. H., \& Anderson, K. A. (2012). A Person-Centered Investigation of Academic Motivation and Its Correlates in High School. Learning and Individual Differences, 22, 429-438.

Wray-Lake, L., Crouter, A. C., \& MacHale, S. M. (2010). Developmental Patterns in Decision-Making Autonomy across Middle Childhood and Adolescence: European American Parents' Perspectives. Child Development, 81, 636-651. https://doi.org/10.1111/j.1467-8624.2009.01420.x

Young, A. E. (2010). Explorations of Metacognition among Academically Talented Middle and High School Mathematics Students. Ph.D. Thesis, Berkeley, CA: University of California.

Young, A., \& Fry, J. D. (2008). Metacognitive Awareness and Academic Achievement in College Students. Journal of the Scholarship of Teaching and Learning, 8, 1-10. 
Zimmerman, B. J. (1989). A Social Cognitive View of Self-Regulated Academic Learning. Journal of Educational Psychology, 81, 329-339.

Zimmerman, B. J. (1990). Self-Regulated Learning and Academic Achievement: An Overview. Educational Psychologist, 25, 3-17.

Zimmerman, B. J. (2002). Becoming a Self-Regulated Learner: An Overview. Theory into Practice, 41, 64-70. https://doi.org/10.1207/s15430421tip4102_2

Zimmerman, B. J. (2008). Investigating Self-Regulation and Motivation: Historical Background, Methodological Developments, and Future Prospects. American Educational Research Journal, 45, 166-183. https://doi.org/10.3102/0002831207312909

Zimmerman, B. J., \& Labuhn, S. S. (2012). Self-Regulation of Learning: Process Approaches to Personal Development. In K. R. Harris, S. Graham, and T. Urdan (Eds.). The Educational Psychology Handbook, Volume 1: Theories, constructs, and Critical Issues (pp. 399-425). Washington DC: American Psychological Association.

Zimmerman, B. J., \& Martinez-Pons, M. (1986). Development of a Structured Interview for Assessing Student Use of Self-Regulated Learning Strategies. American Educational Research Journal, 23, 614-628. https://doi.org/10.3102/00028312023004614

Zimmerman, B. J., \& Schunk, D. H. (2010). Self-Regulated Learning and Academic Achievement: Theoretical Perspectives (2nd ed.). Mahwah, NJ: Lawrence Erlbaum Associates.

Zimmerman, B. J., \& Schunk, D. H. (2011). Self-Regulated Learning and Performance. In B. J. Zimmerman, \& D. H. Schunk (Eds.), Handbook of Self-Regulation of Learning and Performance (pp. 1-12). New York: Routledge.

Zmmerman, B. J., \& Martinez-Pons, M. (1990). Student Differences in Self-Regulated Learning: Relating Grade, Sex, and Giftedness to Self-Efficacy and Strategy Use. Journal of Educational Psychology, 82, 51-59. https://doi.org/10.1037/0022-0663.82.1.51

Zumbrunn, S., Tadlock, J., \& Roberts, E. D. (2011). Encouraging Self-Regulated Learning in the Classroom: A Review of the Literature. Metropolitan Educational Research Consortium (MERC), Virginia Commonwealth University. 